\title{
Parkinson's disease and cancer: a systematic review and meta- analysis on the influence of lifestyle habits, genetic variants, and gender
}

\author{
Joon Yan Selene Lee ${ }^{1}$, Jing Han $\mathrm{Ng}^{2}$, Seyed Ehsan Saffari, ${ }^{1,2}$, Eng-King Tan ${ }^{1,2}$ \\ ${ }^{1}$ Department of Neuroscience and Behavioural Disorders Programme, Duke-NUS Medical School, Singapore \\ ${ }^{2}$ Department of Neurology, National Neuroscience Institute, Singapore
}

Correspondence to: Eng-King Tan; email: gnrtek@sgh.com.sg

Keywords: Parkinson's disease, cancer, LRRK2, meta-analysis, systematic review

Received: November 16, 2021 Accepted: February 15, $2022 \quad$ Published: March 5, 2022

Copyright: (C) 2022 Lee et al. This is an open access article distributed under the terms of the Creative Commons Attribution License (CC BY 3.0), which permits unrestricted use, distribution, and reproduction in any medium, provided the original author and source are credited.

\section{ABSTRACT}

Purpose: The relationship between Parkinson's disease (PD) and cancer has been debated. Gender and genetic influences on cancer development in PD is unclear.

Methods: Using QUOROM guidelines, we conducted a systematic review and meta-analysis on potential clinical and genetic factors influencing the PD and subsequent cancer relationship. English articles published in PubMed, Web of Science, and SCOPUS from 2010 to 30 August 2020 were considered for suitability.

Results: Of 46 studies identified, fourteen satisfied the inclusion criteria and were further analysed. Unadjusted risk ratios (RR) and 95\% confidence intervals were computed to determine the PD and cancer relationship. PD patients have decreased subsequent cancer risks $(R R=0.87,95 \% \mathrm{Cl}=0.81-0.93)$, reduced risks of colon, rectal, and colorectal cancer $(\mathrm{RR}=0.77,95 \% \mathrm{Cl}=0.63-0.94)$, lung cancer $(\mathrm{RR}=0.62,95 \% \mathrm{Cl}=$ $0.48-0.80)$, and increased brain cancer $(R=1.48,95 \% \mathrm{Cl}=1.02-2.13)$ and melanoma risk $(\mathrm{R}=1.76,95 \% \mathrm{Cl}=$ 1.23-2.50). Compared to idiopathic PD, LRRK2-G2019S carriers had increased general cancer risks (RR = $1.26,95 \% \mathrm{Cl}=1.09-1.46)$, particularly brain $(\mathrm{RR}=2.41,95 \% \mathrm{Cl}=1.06-5.50)$, breast $(\mathrm{RR}=2.57,95 \% \mathrm{Cl}=$ 1.19-5.58), colon $(R R=1.83,95 \% \mathrm{Cl}=1.13-2.99)$, and haematological cancers $(\mathrm{RR}=2.05,95 \% \mathrm{Cl}=1.07-$ 3.92). Female PD patients have decreased general cancer risks compared to male PD patients in this analysis $(\mathrm{RR}=0.83,95 \% \mathrm{Cl}=0.69-0.98)$.

Conclusion: PD patients have reduced risks of colon, rectal, colorectal cancer and lung cancers and increased risks of brain cancer and melanoma. LRRK2-G2019S carriers have increased cancer risks, particularly brain, breast, colon and blood cancers. Female gender was associated with reduced risks. The role of ethnicity, comorbidities, and lifestyle habits on PD patients' subsequent cancer risk should be further investigated.

\section{INTRODUCTION}

Parkinson's disease (PD) is a neurodegenerative disease characterized by resting tremors, bradykinesia, and rigidity [1]. The burden of disease to PD patients, their caregivers, and society is high. PD has been associated with an increase in disability-adjusted life years (one of the leading causes of years lived with disability [2]).

Intriguingly, studies have identified a relationship between cancer development following PD diagnosis. Several studies uncovered a positive relationship between PD and subsequent melanoma [3, 4], while 
some found a null relationship $[5,6]$. Other studies also noted melanoma development after levodopa use, the standard PD pharmacological therapy [7].

Clearly, existing studies investigating the link between PD and subsequent melanoma have reached different conclusions. Furthermore, PD was associated with increased risks of breast [4], non-melanocytic [8], and brain cancer [9], but decreased prostate, bladder, and colorectal cancer risks [10]. Risk factors including gender, gene variants implicated in PD pathogenesis, and lifestyle habits like smoking, were also found to have effects on cancer risk following PD diagnosis, further adding to the debate.

Cancer is characterized by aberrant and uncontrolled proliferation [11], directly opposing PD pathogenesis. However, like PD, cancer is crippling due to the physical decline, high mortality, treatment effects, and psychological trauma involved [12]. This makes it more pertinent to interrogate the link between PD and subsequent cancer risk, to identify and treat both diseases early, and more importantly identify factors (such as gender, genetic predisposition, and lifestyle habits) that may influence the association between PD and cancer. Collectively, these efforts can reduce the overall disease burden associated with both pathologies.

To address these gaps in knowledge, we conduct a systematic review and meta-analysis (including casecontrol and cohort studies published between 1 January 2010 and 30 August 2020) to investigate the association of specific cancers with PD and the possible role of lifestyle, gender and genetic risk factors.

\section{RESULTS}

\section{Included studies}

Fourteen studies were included in this meta-analysis, conducted in accordance with the Quality of Reporting of Meta-analyses (QUOROM) guidelines (Figure 1, Supplementary Table 1).

The details of the 14 studies are provided in Table 1 . Reasons for excluding studies investigating PD's impact on subsequent cancer risk, despite meeting the eligibility criteria, are detailed in Supplementary Table 2.

Subgroup analysis comparing cancer risk after PD diagnosis in LRRK2-G2019S mutation carriers and idiopathic PD patients included six studies. Three studies were included in the primary analysis [13-15] while three [16-18] were identified during the initial database search. The characteristics of these six studies are summarized in Supplementary Table 3.
Similarly, analysis comparing the cancer risk after PD diagnosis between female and male PD patients included four studies. Three studies $[4,19,20]$ were included in the primary analysis, while one [6] was identified during the initial database search. The characteristics of the four studies are summarized in Supplementary Table 4.

\section{General cancer risks and heterogeneity of studies}

In this study, PD was associated with a reduced relative risk of subsequent cancer development $(\mathrm{RR}=0.87,95 \%$ $\mathrm{CI}=0.81-0.93$; data not shown). This association held true even after sensitivity analysis $(\mathrm{RR}=0.87,95 \% \mathrm{CI}$ $=0.80-0.93$; Figure 2 ). This is consistent with previous studies indicating an inverse relationship between PD and cancer.

\section{Risk of specific cancers}

Subgroup analysis revealed that PD is associated with a decrease in smoking-related cancers, including colon, rectal, and colorectal cancer $(\mathrm{RR}=0.77,95 \% \mathrm{CI}=$ $0.63-0.94)$, lung cancer $(\mathrm{RR}=0.62,95 \% \mathrm{CI}=0.48$ $0.80)$, and oral cancers ( $\mathrm{RR}=0.73,95 \% \mathrm{CI}=0.52$ 1.03; Figure 2), even though statistical significance was not reached for oral cancer.

The subgroup analysis also showed that PD was associated with an increased risk of brain cancers $(\mathrm{RR}=$ $1.48,95 \% \mathrm{CI}=1.02-2.13)$ and melanoma $(\mathrm{RR}=1.76$, $95 \% \mathrm{CI}=1.23-2.50$; Figure 2). These conclusions are consistent with earlier findings $[9,21,22]$.

\section{Increased cancer risks in LRRK2-G2019S PD patients}

A comparison of subsequent cancer risk in LRRK2G2019S PD and idiopathic PD patients revealed that LRRK2-G2019S PD patients had an increased risk of cancer in general $(\mathrm{RR}=1.26,95 \% \mathrm{CI}=1.09-1.46$; Figure 3). This increase was particularly seen in brain $(\mathrm{RR}=2.41,95 \% \mathrm{CI}=1.06-5.50)$, breast $(\mathrm{RR}=2.57$, $95 \% \mathrm{CI}=1.19-5.58)$, colon $(\mathrm{RR}=1.83,95 \% \mathrm{CI}=$ 1.13-2.99), and hematological cancers $(\mathrm{RR}=2.05,95 \%$ $\mathrm{CI}=1.07-3.92$; Figure 3 ).

\section{Decreased cancer risks in female PD patients}

Female PD patients have a decreased general cancer risk compared to male $\mathrm{PD}$ patients in this analysis (RR $=0.83,95 \% \mathrm{CI}=0.69-0.98$; Figure 4 ). In terms of specific cancers, there was a decreased risk of bladder $(\mathrm{RR}=0.21,95 \% \mathrm{CI}=0.14-0.32)$, colon $(\mathrm{RR}=0.55$, 95\% CI $=0.36-0.83)$, hematological $(\mathrm{RR}=0.52,95 \%$ $\mathrm{CI}=0.36-0.75)$, kidney $(\mathrm{RR}=0.29,95 \% \mathrm{CI}=0.24$ $0.35)$, liver $(\mathrm{RR}=0.39,95 \% \mathrm{CI}=0.31-0.49)$, lung 
$(\mathrm{RR}=0.51,95 \% \mathrm{CI}=0.30-0.84)$, rectal $(\mathrm{RR}=0.37$, $95 \% \mathrm{CI}=0.32-0.44)$, and stomach cancer $(\mathrm{RR}=0.40$, $95 \% \mathrm{CI}=0.22-0.70$; Figure 4$)$.

\section{DISCUSSION}

We showed that PD patients have decreased subsequent cancer risks $(\mathrm{RR}=0.87,95 \% \mathrm{CI}=0.81-0.93)$, with a reduced risk of colon, rectal, and colorectal cancer (RR $=0.77,95 \% \mathrm{CI}=0.63-0.94)$, lung cancer $(\mathrm{RR}=0.62$, $95 \% \mathrm{CI}=0.48-0.80)$. There was an increased brain cancer $(\mathrm{R}=1.48,95 \% \mathrm{CI}=1.02-2.13)$ and melanoma risk $(\mathrm{R}=1.76,95 \% \mathrm{CI}=1.23-2.50)$. Compared to idiopathic PD, LRRK2-G2019S carrier patients had an increased risk of cancer in general $(\mathrm{RR}=1.26,95 \% \mathrm{CI}$ $=1.09-1.46)$, especially for brain $(\mathrm{RR}=2.41,95 \% \mathrm{CI}=$ 1.06-5.50), breast $(\mathrm{RR}=2.57,95 \% \mathrm{CI}=1.19-5.58)$, colon $(\mathrm{RR}=1.83,95 \% \mathrm{CI}=1.13-2.99)$, and hematological cancers $(\mathrm{RR}=2.05,95 \% \mathrm{CI}=1.07-$ 3.92). Female PD patients have a decreased general cancer risk compared to male $\mathrm{PD}$ patients in this analysis $(\mathrm{RR}=0.83,95 \% \mathrm{CI}=0.69-0.98)$.

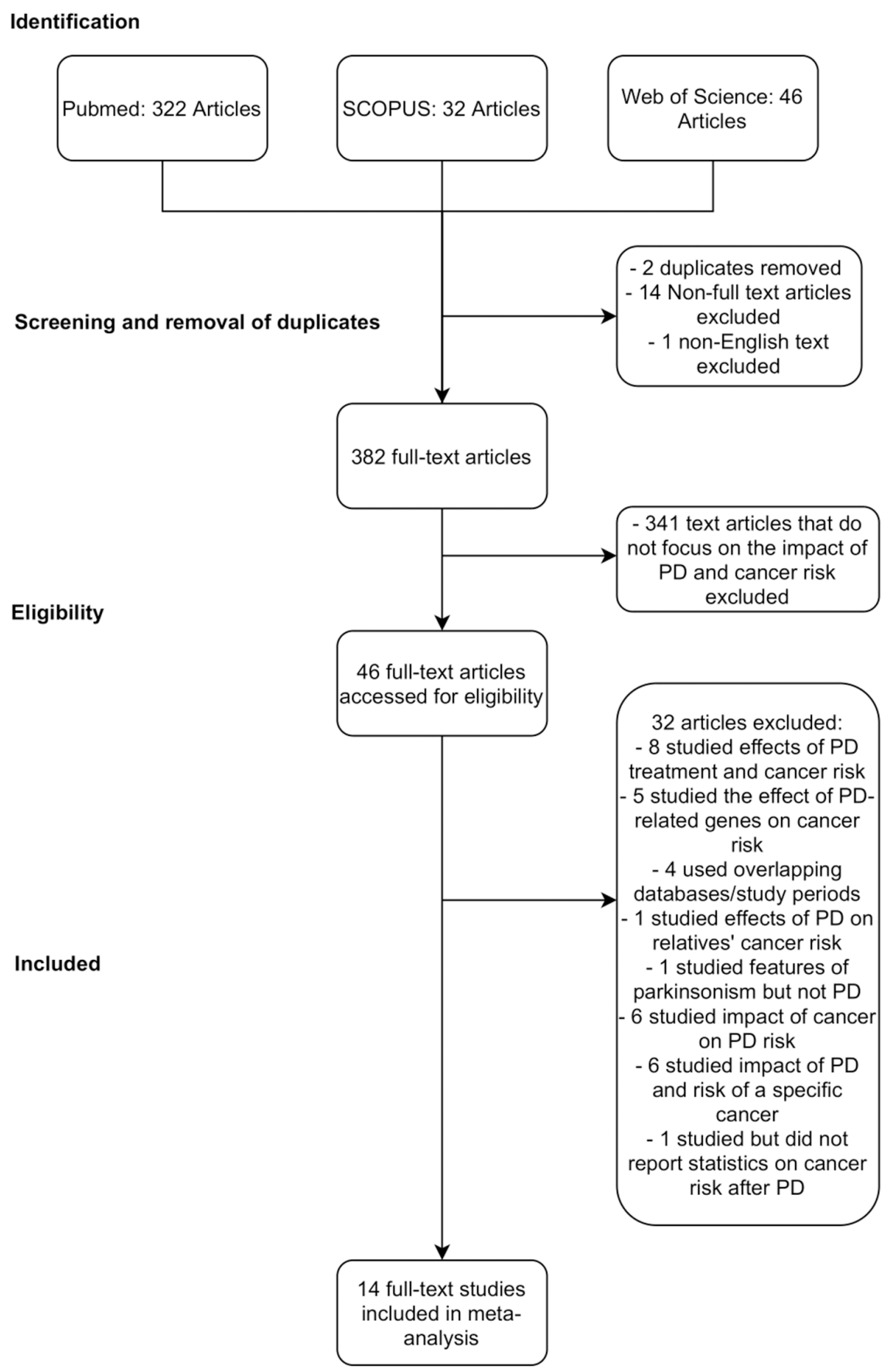

Figure 1. PRISMA chart detailing database search procedure and exclusion criteria. 
Table 1. Characteristics of all studies included in the meta-analysis.

\begin{tabular}{|c|c|c|c|c|c|c|c|c|}
\hline No. & Author & $\begin{array}{l}\text { Study } \\
\text { design }\end{array}$ & Country & Sample size & $\begin{array}{l}\text { Females } \\
(\%)\end{array}$ & $\begin{array}{l}\text { Mean } \\
\text { age (SD) }\end{array}$ & Adjustment & Cancer (s) reported \\
\hline 1 & Lin, 2015 & Cohort & Taiwan & $\begin{array}{l}62023 \text { PD patients } \\
124046 \text { non-PD } \\
\text { controls }\end{array}$ & $\begin{array}{l}94458 \\
(50.7 \%)\end{array}$ & NR & Sex, age & $\begin{array}{l}\text { Cancer in general, brain, melanoma, } \\
\text { kidney, liver, uterus (women), } \\
\text { oesophagus, skin, prostate (men), } \\
\text { gallbladder, lymphoma/leukaemia, } \\
\text { stomach, bladder, lung, pancreas, } \\
\text { colorectal, cervical (women), breast } \\
\text { (women), thyroid, ovary (women) }\end{array}$ \\
\hline 2 & Fois, 2010 & Cohort & UK & $\begin{array}{l}4355 \text { PD patients } \\
\text { Compared to } \\
\text { general population }\end{array}$ & $\begin{array}{l}2205 \\
(50.6 \%)\end{array}$ & NR & $\begin{array}{l}\text { Sex, age in } 5 y \text { bands, time period } \\
\text { (years), district of residence }\end{array}$ & $\begin{array}{l}\text { Cancer in general, oral cavity, pharynx, } \\
\text { lip, larynx, oesophageal, stomach, } \\
\text { colon, rectum, pancreas, lung, breast, } \\
\text { cervix, ovary, uterus, prostate, kidney, } \\
\text { bladder, malignant melanoma, other } \\
\text { skin cancer, malignant brain, bone, } \\
\text { lymphoma, non-Hodgkin's lymphoma, } \\
\text { multiple myeloma, leukaemia, lymphoid } \\
\text { leukaemia, myeloid leukaemia, benign } \\
\text { brain }\end{array}$ \\
\hline 3 & Peretz, 2016 & Cohort & Israel & $\begin{array}{l}7125 \text { PD patients } \\
\text { Compared to } \\
\text { general population }\end{array}$ & $\begin{array}{l}3297 \\
(46.3 \%)\end{array}$ & $\begin{array}{l}71.1 \\
(10.6)\end{array}$ & Age, chronological year, sex & $\begin{array}{l}\text { Cancer in general, breast (women), } \\
\text { colon, CNS, kidney, leukaemia, lung, } \\
\text { lymphoma, melanoma, ovary, pancreas, } \\
\text { prostate (men), rectum, thyroid }\end{array}$ \\
\hline 4 & Park, 2019 & Cohort & $\begin{array}{l}\text { South } \\
\text { Korea }\end{array}$ & $\begin{array}{l}52009 \text { PD patients } \\
260045 \text { non-PD } \\
\text { controls }\end{array}$ & $\begin{array}{l}184776 \\
(59.2 \%)\end{array}$ & $71(10)$ & $\begin{array}{l}\text { Diabetes mellitus, hypertension, } \\
\text { dyslipidaemia, income status }\end{array}$ & $\begin{array}{l}\text { Cancer in general, oral cavity and } \\
\text { pharyngeal, laryngeal, oesophageal, } \\
\text { gastric, colorectal, liver, pancreatic, } \\
\text { biliary, lung, renal, bladder, thyroid, } \\
\text { leukaemia, lymphoma, multiple } \\
\text { myeloma, skin, breast (women), uterine } \\
\text { cervical (women), uterine corpus } \\
\text { (women), ovarian (women), prostate } \\
\text { (men), testicular (men) }\end{array}$ \\
\hline 5 & Lo, 2010 & Cohort & USA & $\begin{array}{l}692 \text { PD patients } \\
761 \text { non-PD } \\
\text { controls }\end{array}$ & $\begin{array}{l}544 \\
(37.4 \%)\end{array}$ & $\begin{array}{l}65.9 \\
(12.1)\end{array}$ & $\begin{array}{l}\text { Age, sex, cigarette smoking (pack } \\
\text { years), alcohol consumption (number } \\
\text { of drinks per month), BMI, eye } \\
\text { colour }\end{array}$ & $\begin{array}{l}\text { Cancer in general, smoking-related } \\
\text { cancer, non-smoking related cancer, } \\
\text { lung, bladder, breast (women), prostate } \\
\text { (men), colorectal, melanoma }\end{array}$ \\
\hline 6 & Liat, 2014 & Cohort & UK & $\begin{array}{l}219194 \mathrm{PD} \\
\text { patients } \\
9015614 \text { non-PD } \\
\text { controls }\end{array}$ & $43 \%$ & NR & NR & $\begin{array}{l}\text { Cancer in general, bladder, bone, brain, } \\
\text { breast (women), cervix (women), colon, } \\
\text { upper GI, kidney, larynx, myeloid } \\
\text { leukaemia, lymphoid leukaemia, liver, } \\
\text { lung, Hodgkin's lymphoma, non- } \\
\text { Hodgkin's lymphoma, malignant } \\
\text { melanoma, multiple myeloma, } \\
\text { nasopharynx, meninges, oesophageal, } \\
\text { ovary (women), pancreas, prostate, } \\
\text { rectum, salivary gland, non-melanoma } \\
\text { skin cancer, stomach, testis (men), } \\
\text { thyroid, uterus corpus (women) }\end{array}$ \\
\hline 7 & $\begin{array}{l}\text { Rugbjerg, } \\
2012\end{array}$ & Cohort & Denmark & $\begin{array}{l}20343 \text { PD patients } \\
\text { Compared to } \\
\text { general population }\end{array}$ & $\begin{array}{l}9631 \\
(47.3 \%)\end{array}$ & 72.7 & NR & $\begin{array}{l}\text { Cancer in general, malignant melanoma, } \\
\text { non-melanoma skin, breast (women), } \\
\text { larynx, lung, urinary bladder, ovary, } \\
\text { fallopian tube and bread ligament } \\
\text { (women), colorectal, prostate (men), } \\
\text { non-Hodgkin lymphoma, corpus uteri } \\
\text { (women), brain, multiple myeloma, } \\
\text { lymphatic leukaemia, unspecified }\end{array}$ \\
\hline 8 & $\begin{array}{l}\text { Wirdefeldt, } \\
2014\end{array}$ & Cohort & Sweden & $\begin{array}{l}11786 \text { PD patients } \\
58930 \text { non-PD } \\
\text { controls }\end{array}$ & $\begin{array}{l}27906 \\
(39.5 \%)\end{array}$ & $62.5(9.2)$ & Education level & $\begin{array}{l}\text { Cancer in general, mouth, oesophageal, } \\
\text { stomach, liver, pancreas, nose and nasal } \\
\text { sinuses, larynx, trachea, bronchus, lung } \\
\text { and pleura, cervix uteri (women), } \\
\text { kidney and urinary organs, small } \\
\text { intestine, peritoneum, mediastinum, } \\
\text { breast (women), prostate (men), testis } \\
\text { (men), malignant melanoma of skin, } \\
\text { skin (excluding melanoma), endocrine }\end{array}$ \\
\hline
\end{tabular}


glands, bone, connective tissue or muscle, nervous system, colon, rectum, anus, lymphoma, corpus uteri (women), ovary (women), male genital organs other than prostate and testis, thyroid gland, multiple myeloma, lymphatic leukaemia, unspecified

\begin{tabular}{|c|c|c|c|c|c|c|c|c|}
\hline $9 \mathrm{a}$ & Becker, 2010 & Cohort & UK & $\begin{array}{l}2993 \text { PD patients } \\
3003 \text { non-PD } \\
\text { controls }\end{array}$ & NR & NR & NR & $\begin{array}{l}\text { Cancer in general, lung, larynx, } \\
\text { pharynx, buccal cavity, stomach, } \\
\text { urinary tract, oesophageal, pancreas, } \\
\text { breast (women), colorectal, prostate } \\
\text { (men), lymphoma/leukaemia, female } \\
\text { reproductive organs, CNS, liver, } \\
\text { gallbladder, thyroid gland, unspecified }\end{array}$ \\
\hline $9 b^{1}$ & Becker, 2010 & $\begin{array}{l}\text { Case- } \\
\text { control }\end{array}$ & UK & $\begin{array}{l}1118 \text { PD patients } \\
1212 \text { non-PD } \\
\text { controls }\end{array}$ & NR & NR & NR & $\begin{array}{l}\text { Cancer in general, lung, larynx, } \\
\text { pharynx, buccal cavity, stomach, } \\
\text { urinary tract, oesophageal, pancreas, } \\
\text { breast (women), colorectal, prostate } \\
\text { (men), lymphoma/leukaemia, female } \\
\text { reproductive organs, CNS, liver, } \\
\text { gallbladder, thyroid gland, unspecified }\end{array}$ \\
\hline 10 & Agalliu, 2019 & $\begin{array}{l}\text { Case- } \\
\text { control }\end{array}$ & $\begin{array}{l}\text { Europe, } \\
\text { Israel, } \\
\text { USA }\end{array}$ & $\begin{array}{l}712 \text { PD patients } \\
218 \text { non-PD } \\
\text { controls }\end{array}$ & $\begin{array}{l}419 \\
(45.1 \%)\end{array}$ & $\begin{array}{l}66.9 \\
(10.9)\end{array}$ & $\begin{array}{l}\text { Age, sex, Ashkenazi Jews ethnicity } \\
\text { (fixed effect) and study centre } \\
\text { (random effect), smoking status, BMI }\end{array}$ & $\begin{array}{l}\text { Cancer in general, skin cancer, } \\
\text { melanoma, lung cancer, bladder cancer, } \\
\text { breast (women), ovarian (women), } \\
\text { prostate (men), colon, kidney/renal, } \\
\text { haematologic/lymphoma, meningioma }\end{array}$ \\
\hline 11 & $\begin{array}{l}\text { Ruiz- } \\
\text { Martínez, } \\
2014\end{array}$ & $\begin{array}{l}\text { Case- } \\
\text { control }\end{array}$ & Spain & $\begin{array}{l}637 \text { PD patients } \\
176 \text { non-PD } \\
\text { controls }\end{array}$ & $\begin{array}{l}415 \\
(51.0 \%)\end{array}$ & $\begin{array}{l}71.2 \\
(12.0)\end{array}$ & Age & $\begin{array}{l}\text { Cancer in general, melanoma, lung, } \\
\text { bladder, colon, kidney, breast (women), } \\
\text { ovarian (women), prostate (men), } \\
\text { hormonal, haematologic, meningioma, } \\
\text { unspecified }\end{array}$ \\
\hline 12 & $\begin{array}{l}\text { Freedman, } \\
2015\end{array}$ & $\begin{array}{l}\text { Case- } \\
\text { control }\end{array}$ & USA & $\begin{array}{l}6994 \text { PD patients } \\
972822 \text { non-PD } \\
\text { controls }\end{array}$ & $\begin{array}{l}445388 \\
(45.5 \%)\end{array}$ & $\begin{array}{l}\text { NR } \\
\text { (Median } \\
\text { age }=74 \\
\text { years) }\end{array}$ & $\begin{array}{l}\text { Age, race, sex, number of doctors' } \\
\text { visits, cancer registry area and } \\
\text { selection years }\end{array}$ & $\begin{array}{l}\text { Cancer in general, oral cavity, } \\
\text { oesophageal, stomach, colon, rectum, } \\
\text { pancreas, larynx, lung and bronchus, } \\
\text { melanoma, breast (women), cervix } \\
\text { (women), uterus (women), ovary } \\
\text { (women), prostate (men), urinary } \\
\text { bladder, kidney/renal pelvis, thyroid, } \\
\text { leukaemia }\end{array}$ \\
\hline 13 & Tacik, 2016 & $\begin{array}{l}\text { Case- } \\
\text { control }\end{array}$ & USA & $\begin{array}{l}971 \text { PD patients } \\
478 \text { non-PD } \\
\text { controls }\end{array}$ & $\begin{array}{l}840 \\
(58.0 \%)\end{array}$ & $\begin{array}{l}\text { NR } \\
\text { (median } \\
\text { age }=67 \\
\text { years) }\end{array}$ & $\begin{array}{l}\text { Age and sex (except for sex-specific } \\
\text { cancers - breast, prostate, ovarian, } \\
\text { uterine, testicular) } \\
\text { No adjustment - For cancers with } \\
<10 \text { patients }\end{array}$ & $\begin{array}{l}\text { Cancer in general, breast (women), } \\
\text { colon, leukaemia, lymphoma, prostate } \\
\text { (males), bladder, pancreatic, melanoma, } \\
\text { nonmelanoma skin cancer, any skin } \\
\text { cancer, ovarian (women), lung, brain, } \\
\text { stomach, bile duct, uterine (women), } \\
\text { oesophageal, liver, thyroid, bone, } \\
\text { kidney, testicular (men) }\end{array}$ \\
\hline 14 & Shalaby, 2016 & $\begin{array}{l}\text { Case- } \\
\text { control }\end{array}$ & USA & $\begin{array}{l}108 \text { PD patients } \\
124 \text { non-PD } \\
\text { controls }\end{array}$ & $\begin{array}{l}127 \\
(54.7 \%)\end{array}$ & $\begin{array}{l}71.4 \\
(7.94)\end{array}$ & $\begin{array}{l}\text { 1. Liberal adjusted (any cancer): } \\
\text { Number of prescription } \\
\text { medications, age in years, } \\
\text { Caucasian race, Cumulative } \\
\text { Illness Rating Scale Score } \\
\text { 2. Liberal adjusted (melanoma): } \\
\text { Number of prescription } \\
\text { medications } \\
\text { 3. Liberal adjusted (integumentary } \\
\text { cancers): Number of prescription } \\
\text { medications, years since last } \\
\text { hospitalisation } \\
\text { 4. Conservative adjusted (all } \\
\text { cancers, melanoma, } \\
\text { integumentary cancers): Similar } \\
\text { to unadjusted model - Include } \\
\text { variables associated with both the } \\
\text { cancer and the diagnosis }\end{array}$ & $\begin{array}{l}\text { Cancer in general, basal cell, squamous } \\
\text { integumentary, brain, squamous } \\
\text { mesodermal, breast (women), } \\
\text { lymphoma, lymphoma, myeloma, } \\
\text { leukaemia, oral cavity/pharynx, uterine } \\
\text { (women), ovarian (women), prostate } \\
\text { (men), urinary/bladder, kidney, thyroid, } \\
\text { gastric, colon, liver, pancreas, } \\
\text { unspecified }\end{array}$ \\
\hline
\end{tabular}

Abbreviations: PD: Parkinson's Disease; NR: Not reported; BMI: Body mass index; GI: Gastrointestinal. 


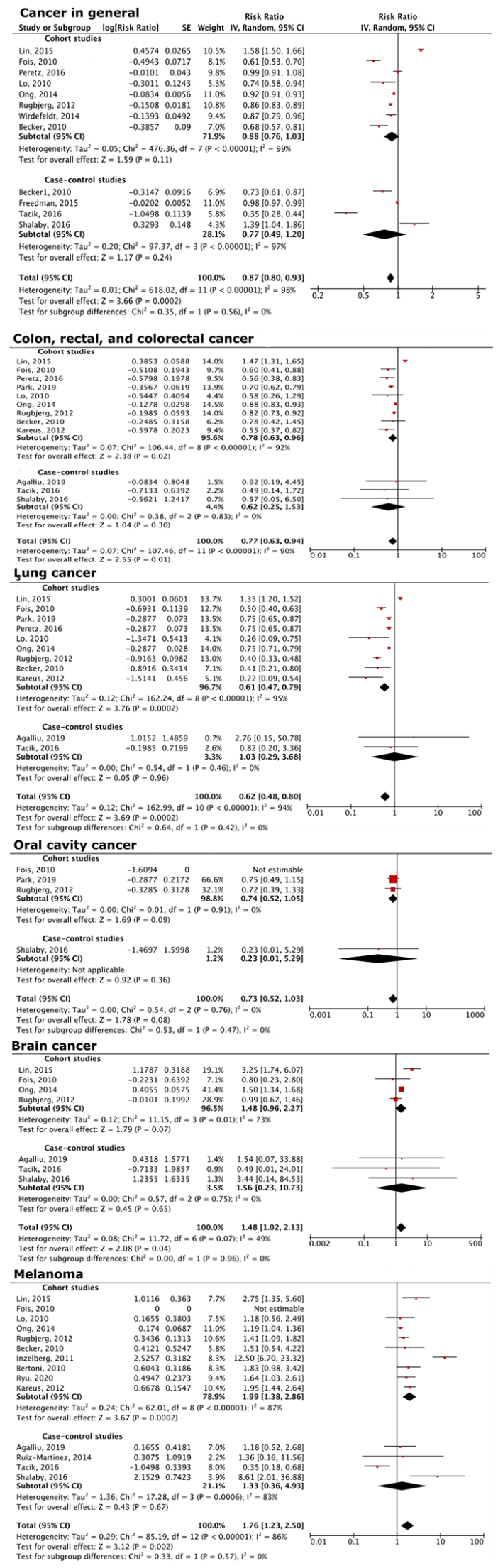

Figure 2. Forest plot of the association between PD and overall cancer risk, as well as that of specific cancers. PD patients had decreased overall cancer risks, and decreased risks of colon, rectal, colorectal, lung, oral cavity, brain cancers, and melanoma, compared to the general population. 
Several hypotheses could explain the above observations. These include opposing molecular pathways between PD and cancer, lifestyle changes in PD patients following PD diagnosis, and an increased rate of healthcare utilization and surveillance among PD patients compared to non-PD individuals.

\section{Opposing molecular pathways of PD and cancer}

PD involves degeneration of the dopamine producing cells of the substantia nigra, while cancer, with its proliferative nature [23], lies on the opposite end of the spectrum. Several PD-related genes have been found

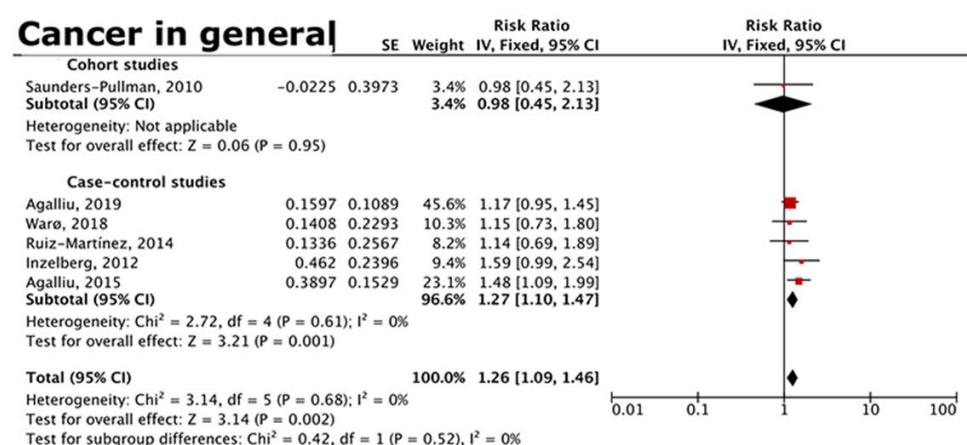

Test for subgroup differences: $\mathrm{Chi}^{2}=0.42, \mathrm{df}=1(P=0.52), \mathrm{I}^{2}=0 \%$

\section{Brain cancer}

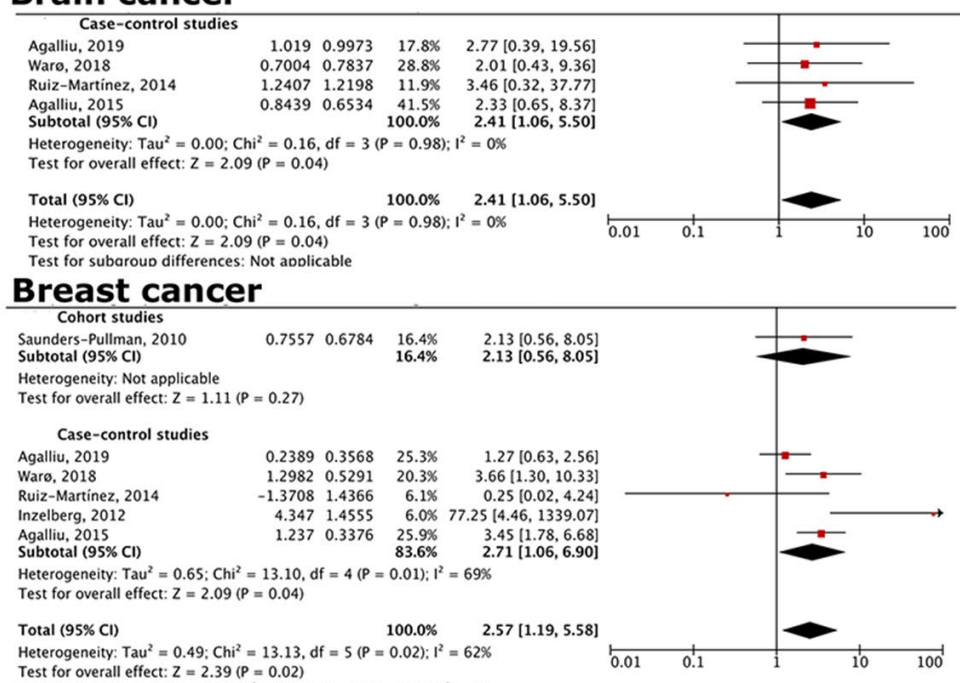

Test for overall effect: $Z=2.39(P=0.02)$

Test for subgroup differences: $\mathrm{Ch}^{2}=0.08, \mathrm{df}=1(P=0.77), \mathrm{I}^{2}=0 \%$

\section{Colon cancer}

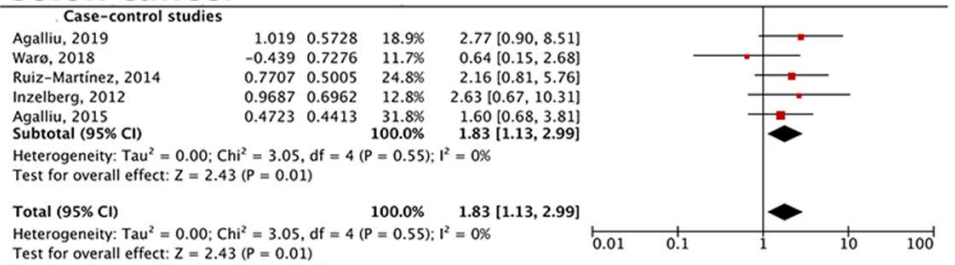

Heterogeneity: $\mathrm{Tau}^{2}=0.00 ; \mathrm{Chi}^{2}=3.05, \mathrm{df}=4(\mathrm{P}=0.55) ; \mathrm{I}^{2}=0 \%$
Test for overall effect: $Z=2.43(P=0.01)$

Test for overall effect. $2=2.43(P=0.01)$

Haematological cancer

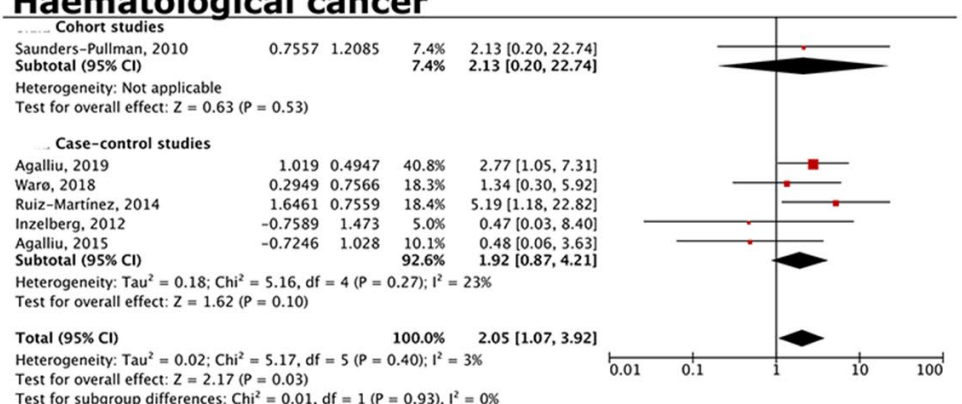

Figure 3. Forest plot comparing risks of cancer in general and specific cancers for LRRK2-PD vs. idiopathic PD patients. LRRK2-PD patients had higher risk of overall cancer, as well as brain, breast, colon, and hematological cancers. 
to possibly mediate the relationship between PD and subsequent cancer. These genes include LRRK2, PARK2, a tumor suppressor gene, PARK5, coding for the ubiquitin carboxyl-terminal hydrolase-L1 (UCH-L1) enzyme involved in ubiquitin-recycling, PARK7 (DJ-1), a strong anti-oxidant, and PARK6 (PINK1), a cell death and cell cycle regulator [23]. Oxidative damage, alterations in protein ubiquitination, and cell cycle dysregulation have been implicated in cancer pathogenesis [24]. Therefore, the PARK family proteins involved both in PD and regulation of replication stress can possibly mediate both pathologies.

\section{Lifestyle changes in PD patients}

Amongst PD patients, a 'Parkinsonian personality' characterized by low novelty seeking (NS) and high harm avoidance (HA) behavior, possible resulting from decreased dopaminergic stimulation, has been described [25]. NS behaviors include impulsivity, reward seeking,
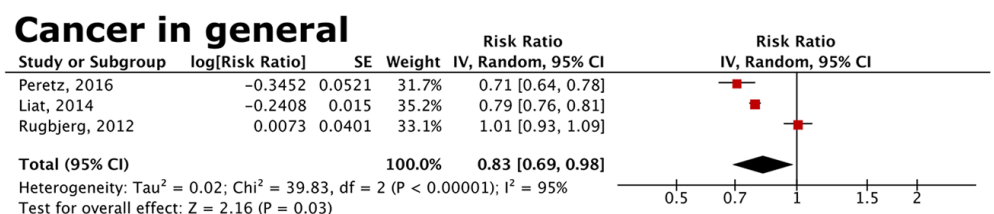

Bladder cancer

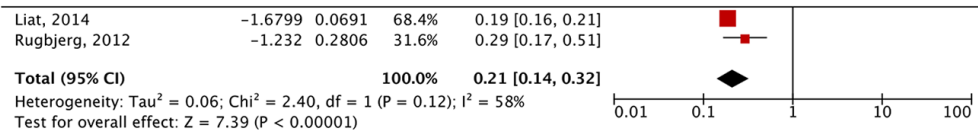

Colon cancer

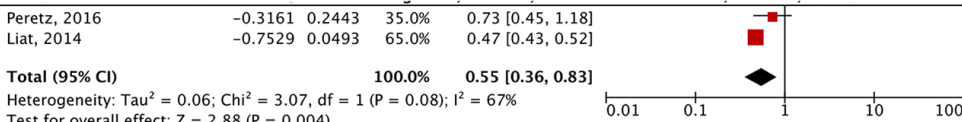

Heterogeneity: $\mathrm{Tau}^{2}=0.06 ; \mathrm{Chi}^{2}=3.07, \mathrm{df}=1(\mathrm{P}=0.08) ; \mathrm{I}^{2}=67 \%$

Haematological cancer

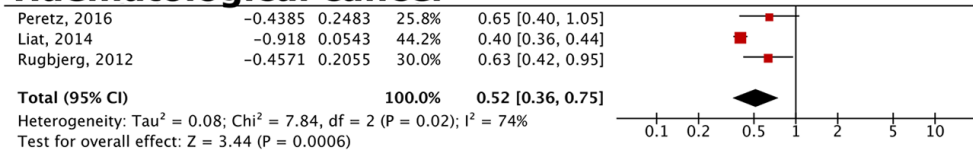

Liver cancer

\begin{tabular}{|c|c|c|c|c|c|c|}
\hline Liat, 2014 & -0.9697 & 0.1245 & $92.4 \%$ & $0.38[0.30,0.48]$ & $\mathbf{\square}$ & \\
\hline Rugbjerg, 2012 & -0.5868 & 0.4328 & $7.6 \%$ & $0.56[0.24,1.30]$ & & \\
\hline Total (9 & & & $100.0 \%$ & $0.39[0.31,0.49]$ & $\bullet$ & \\
\hline
\end{tabular}
Test for overall effect: $Z=7.86(P<0.00001)$

\section{Lung cancer}

\begin{tabular}{|c|c|c|c|c|c|c|c|}
\hline Peretz, 2016 & -0.3972 & 0.3781 & $22.6 \%$ & $0.67[0.32,1.41]$ & & \multirow{3}{*}{\multicolumn{2}{|c|}{$=1$}} \\
\hline Liat, 2014 & -1.043 & 0.0487 & $42.3 \%$ & $0.35[0.32,0.39]$ & & & \\
\hline Rugbjerg, 2012 & -0.4308 & 0.1872 & $35.1 \%$ & $0.65[0.45,0.94]$ & & & \\
\hline Total $(95 \% \mathrm{Cl})$ & & & $100.0 \%$ & $0.51[0.30,0.84]$ & & & \\
\hline \multicolumn{7}{|c|}{$\begin{array}{l}\text { Heterogeneity: } \text { Tau }^{2}=0.16 ; \mathrm{Chi}^{2}=12.55, \mathrm{df}=2(P=0.002) ; 1^{2}=84 \% \\
\text { Test for overall effect: } Z=2.61(P=0.009)\end{array}$} & 20 \\
\hline
\end{tabular}

\section{Rectal cancer}

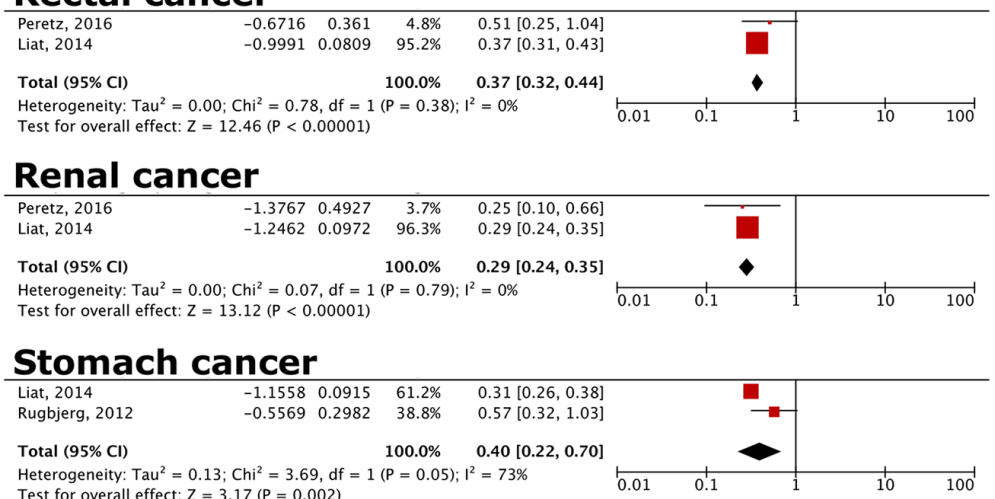
Test for overall effect: $Z=3.17(P=0.002)$

Figure 4. Forest plot comparing risks of cancer in general and specific cancers for female vs. male PD patients. Female PD patients have decreased risks of overall cancer, and bladder, colon, haematological, liver, lung, and rectal cancer compared to male PD patients. Details of specific cancers included in each cancer group are listed in Supplementary Table 6A-6C. 
and exploration of novel experiences, while HA behaviors include pessimism, worry, and avoidance due to uncertainty [25]. While epidemiological research in this domain is lacking, PD patients may possibly be engaging in less risky lifestyle behaviors like smoking and adopting healthier habits of increased physical activity and eating balanced diets. These lifestyle attributes are related to a decreased cancer risk [26], contributing to lower cancer risks seen in our study.

\section{Increased healthcare utilization and surveillance in PD patients}

Tremors, rigidity, and bradykinesia significantly reduces one's ability to perform daily activities [27]. PD patients also tend to have more comorbidities, including obesity, diabetes mellitus, and cardiac pathologies [27].

Furthermore, PD treatment with dopaminergic agonists may lead to complications such as cardiac fibrosis and arrhythmias [27]. The combination of PD-related symptoms, multiple comorbidities, on top of PD treatment effects has necessitated increased expenditure and healthcare utilization rates among PD patients in countries like Brazil [28] and the United States [29]. In the United States, states with higher PD prevalence have increased awareness and recognition of $\mathrm{PD}$ symptoms, further driving healthcare seeking behaviours [29] and comprehensive medical care involving not only neurologists, but also internal medicine physicians [27].

This possibly explains, at least partly, the decreased general cancer risk amongst PD patients, through earlier detection and management.

\section{Risks of specific cancers following PD diagnosis}

\section{Smoking-related cancers}

Evidence of an inverse relationship between smoking and PD development is abundant, with this negative correlation intensified by smoking duration and dose [30]. Chemical substances in cigarettes and cigarette smoke, including nicotine and 2,3,6-trimethyl-1,4napthoquinone (TMN), have been proposed to influence this inverse relationship [30]. TMN is a MAO inhibitor that reduces neurodegeneration induced by metabolites like MPTP [21, 30], while nicotine, acting on the striatal nicotinic receptors, can augment dopamine release [30], or have protective effects leading to dopaminergic neuron survival [21].

Furthermore, the decreased NS and increased HA behaviors previously detailed may lead to decreased smoking rates in PD patients. The biochemical effects of smoking on PD development, coupled with decreased smoking habits, may result in an overall reduced smoking-related cancer observed.

\section{Brain cancers}

Emerging research has pointed towards the neuroprotective effects of the gut microbiome through reducing proinflammatory cytokine production, inducing secretion of the anti-inflammatory interleukin IL-10, and promoting development of Treg cells that play a role in immunosuppression [31]. These effects are due to metabolites produced by the microbiota, especially short chain fatty acids (SCFAs) that have anti-inflammatory, neuroprotective, and anti-oxidant effects [32]. It is also postulated that these metabolites and the mediators induced as a result, could affect blood-brain barrier integrity, influencing susceptibility to neural insults [31].

Gut microbiome biodiversity alteration in PD patients, specifically in the abundance of bacteria in the phylae Firmicutes, Bacteroidetes, and Proteobacteria [33], have been reported. Decreased microbial biodiversity likely led to decreased SCFA production and therefore neuroprotective effects, possibly explaining the increased brain cancer risks.

\section{Melanoma}

Melanoma has consistently been reported to be more prevalent among PD patients. Several lines of evidence, from shared risk factors, common biochemical pathways, and genes, have been put forth to explain this relationship.

Ye et al. (2020) [34] outlined several overlapping characteristics between PD and melanoma: In terms of ethnicity, PD and melanoma were more common in Whites, with both rates increased in individuals with fair skin tones and red hair. In terms of lifestyle behaviors, decreased smoking rates in PD patients were correlated with increased melanoma risks, while coffee consumption was associated with both a decreased PD and melanoma risk.

Biochemically, the pigmentation pathway is shared for melanin production in the skin and neuromelanin in the brain from tyrosine [11]. Melanin in the skin protects cells against DNA damage induced by UV radiation, while neuromelanin is a crucial neuroprotective pigment in the dopaminergic neurons by sequestering reactive oxygen species and metal ions [11]. Alterations in this common pathway resulting in decreased melanin and neuromelanin production may therefore make skin cells more susceptible to genetic instability, and dopaminergic neurons more vulnerable to oxidative damage, possibly linking PD and melanoma. 
Loss of heterozygosity of PARK2, LRRK2 mutations causing neuronal cell death and neurotoxicity, BRAF kinase alterations, and PARK7 oncogene activation with subsequent melanoma development are possible underpinning genetic pathophysiology $[11,34]$.

The combined effect of common risk factors, shared biochemical pathways, and overlapping genes provide strong evidence linking the positive correlation between PD and melanoma occurrence.

\section{Cancer risks in LRRK2-G2019S PD carriers}

LRRK2, a protein kinase gene, is most commonly implicated in familial PD [35]. LRRK2 promotes aggregation of $\alpha$-synuclein into Lewy bodies and tau tangles [35]. In addition, these mutations also contribute to neurodegeneration in PD by driving cells towards a pro-inflammatory state, increasing oxidative stress, and disrupting mitochondrial functions and the autophagylysosomal system [35].

Inflammation, oxidative damage, mitochondrial dysfunction and disruption of the autophagy-lysosomal system are processes unique not only to PD development, but also cancer [36]. It is therefore unsurprising to find increased cancer risks amongst LRRK2-G2019S PD patients in our study, with LRRK2 promoting PD-associated neurodegeneration and cancer-related pathogenesis pathways. Interestingly, in addition to the expression of various LRRK2 mutations, namely R1441C, R1441G, R1441H, and G2019S in the brain [37], LRRK2 has been found in peripheral blood cells [38], gut [39], and in the lung and breast [40]. These expression patterns mirror our findings of increased brain, breast, colon, and hematological cancers, further strengthening the association between LRRK2 and cancer and increasing the value of targeting LRRK2 for therapeutic treatment of both PD and cancer.

LRRK2 has been identified to be a candidate prognostic biomarker for clear cell renal cell carcinoma [41]. Yang et al. [41] showed that there was up regulation (confirmed on immunohistochemical and protein studies) of LRRK2 expression that was associated with DNA methylation in this cancer. Interestingly, somatic LRRK2 truncating or deletion mutations have been identified in malignant mesothelioma and LRRK2 expression was absent or downregulated in primary tumor cell lines [42]. How this tumor suppressor change predispose to cancers still needs to be investigated. A specific LRRK2 rs10878441 CC genotype has been linked to a poorer prognosis in Chinese breast cancer patients [43]. High LRRK2 expression has also been associated with poorer survival in ovarian cancer [44].
It was also demonstrated that inhibiting LRRK2 promoted toxicity of PARP inhibitor by reducing homologous recombination-mediated DNA double strand break repair [44]. LRRK2 is also involved in the ATM-Mdm2-p53 pathway that regulates cell proliferation in response to DNA damage [45]. These clinical and experimental observations provide support linking LRRK2 to cancer.

\section{Decreased cancer risk in female PD patients}

The protective role of estrogen has been well documented in dopaminergic neurons [46], adipose tissues, skeletal muscles, macrophages, and immune cells [47]. Estrogen is neuroprotective, reducing the oxidative damage from dopamine, iron, and calcium [46] that contribute to PD development. In other nonneuronal cells, estrogen modulates fuel metabolism, specifically of lipids, amino acids, and glucose [47], which are commonly dysregulated in cancer cells [36]. This can possibly explain why females with higher lifetime estrogen exposures, and women who have used estrogen therapy have decreased PD [46], as well as cancer risks found in our analysis.

LRRK2 and estrogen have opposing effects on similar domains of inflammation, oxidative stress, and metabolism, with the former toxic and the latter protective in neurons and non-neuronal cells. It may therefore be reasonable to postulate that LRRK2 mutation effects may override the protection afforded by estrogen in female carriers, resulting in more severe PD symptoms and increased cancer risks.

\section{Implications of study}

The identification of potential healthier lifestyle choices and more frequent healthcare monitoring provides increased impetus to encourage PD patients to adopt lifestyle changes and follow-up adherence to reduce both PD progression and cancer development. Furthermore, the involvement of PARK family genes in $\mathrm{PD}$ and cancer pathogenesis opens a new therapeutic angle through targeted downregulation of these genes to reduce risk of contracting either or both pathologies.

While general cancer risk in PD patients was decreased, increased risks of brain cancers and melanoma were found. This prompts a need for more frequent screening for early signs and symptoms of these neoplasms. The gut-brain microbiome's effects and decreased gut biodiversity in PD patients suggest that diet regulation and probiotics to promote improved gut health may be a preventive measure against brain cancers. The common pathway involved in melanin and neuromelanin production, implicated in both melanoma and PD, 
indicates a possible treatment strategy focused on altering the enzyme kinetics as a means of reducing melanoma risks.

The opposing effects of LRRK2 and estrogen on PD and cancer development highlight the potential utility of estrogen replacement to slow PD progression and severity, as well as cancer development in PD patients. This is supported by a prior study [48] indicating that estrogen has beneficial effects on neurons in the nigrostriatum. While further analysis is required to determine the contribution of gender and estrogen effects on the increased cancer risks in LRRK2-PD patients, our findings suggest the potential utility of hormonal therapy as a dual preventive measure for PD and cancer.

\section{Comparison to previous meta-analysis}

Two other meta-analyses investigating the relationship between PD and subsequent cancer development were conducted in 2010 [49], 2019 [50] respectively. However, our study has several strengths.

First, we uniformly extracted unadjusted RRs from the included studies, or manually calculated it from the data provided in the papers or by the authors. In contrast, Bajaj et al. (2010) [49] and Zhang and Liu (2019) [50] extracted and treated adjusted and unadjusted ORs, RRs, SIRs, and HRs equally, under the assumption that PD and cancer are rare conditions. However, with increased prevalence of both diseases $[51,52]$, it is incorrect to make the assumption, and hence only RRs would reflect the true risk of developing cancer after PD. Additionally, since different studies adjusted their results based on different factors, the actual PD effect on subsequent cancer risk can only be compared equally using unadjusted RRs, as in this case.

Second, we provided a concise account of cancer risks in specific PD populations, comparing between male and female patients and between LRRK2-PD and idiopathic PD patients. Although the negative association between $\mathrm{PD}$ and subsequent cancer development found in this study was similar to that of previous meta-analysis [49, 50] additional analyses conducted showed that the decreased risks were more significant in female and idiopathic PD patients.

Identification of specific at-risk subgroups can facilitate management strategies encompassing increased screening and surveillance, lifestyle changes, and hormonal replacement as promising therapeutic options. This study therefore provides a holistic review of not just the relationship shared between PD and cancer, but the multiple factors and probable treatment options for PD patients.

\section{Study limitations}

First, the effects of comorbidities and level of tobacco use could not be analyzed as the information were unavailable. Second, as the included studies were mostly conducted in Western populations, the generalizability of the current findings to an Asian population is unclear.

In conclusion, we demonstrated that PD patients have a reduced risk of colon, rectal, colorectal cancer and lung cancers and an increased risk of brain cancer and melanoma. LRRK2-G2019S carriers have an increased cancer risk, in particular for brain, breast, colon and blood cancers and female gender was associated with a reduced risk of bladder colon, hematological, kidney, liver, lung, rectal, and stomach cancer.

Future gene-environmental and lifestyle prospective studies will be able to identify factors that may modulate the association between PD and cancer. Functional studies in experimental models to elucidate the pathophysiology of PD and cancer contributed by kinase functions and targets of LRRK2 in the cell cycle may facilitate identification of therapeutic targets.

\section{METHODS}

\section{Search strategy}

Database search was conducted on PubMed, Web of Science, and SCOPUS to identify published articles between 1 January 2010-30 August 2020 investigating the incidence and prevalence of cancer following PD diagnosis. "Parkinson disease", "Neoplasm", "Cancer", and "Epidemiological studies" were entered as search topics or medical subject headings and connected with Boolean operators. Where applicable, filters were applied to limit studies to those conducted in humans, in English, and were in full text. The search strategy is detailed in Supplementary Methods.

Searches were performed for each database and were updated until 1 June 2021.Titles and abstracts were screened independently by two reviewers (J.Y.S.L and J.H.N) against a set of pre-defined eligibility criteria. Potentially eligible studies were selected for full-text analysis. Additional relevant studies were identified by manually examining the references provided in the published studies identified initially during the database search. 


\section{Eligibility criteria}

Studies eligible for inclusion in the primary analysis investigated the impact of PD on subsequent cancer development. Data were reviewed to ensure that subjects recruited in the studies were cancer-free before PD diagnosis, regardless of subsequent cancer development. This was done through appraising the study cohorts employed between two independent reviewers. Studies investigating cancer's effect on subsequent PD development, and on cancer risk in relatives of PD patients were not considered. Resolution of disagreements were by consensus after discussion.

Of the studies identified through the initial database search, eight investigated the effect of pharmaceutical PD treatment on cancer risk [17, 53-59], five looked at the impact of genetic variants, such as LRRK2 on cancer development $[13,16-18,60]$ and six investigated PD's effect on the development of specific cancers [3, 22, 56, 58, 61, 62]. Another study [63] investigated PD's impact on subsequent cancer development but did not report the outcome statistics, and was excluded from primary analysis. While these studies were not included in the primary analysis, they were included in subgroup analyses to determine the effect of gender, PD treatment, PD-related genetic variants, or PD's effect on specific cancers.

Studies meeting the eligibility criteria were then analyzed in detail to ensure that there were no overlapping study cohorts. Four Taiwanese $[6,9,64$, $65]$ and two Israeli studies $[19,66]$ utilized the same study cohort in their respective countries. The study that employed the most study subjects and tracked the development of the most cancers in each of the two countries was ultimately chosen.

\section{Exclusion criteria}

This analysis excluded papers that were non-English and conducted in non-human subjects. Non-original research papers, laboratory-based, and epidemiological studies with no clinical characteristics reported were also not considered. Case series and case reports were excluded according to recommendations by the Cochrane Statistical Methods Group and in accordance with methodologies of previously published meta-analyses [67].

\section{Data extraction}

Information from the studies were extracted by two independent reviewers (J.Y.S.L and J.H.N). These included the number of subjects recruited, demographic details inclusive of the mean age, gender distribution, and country where the study was conducted.
Information pertaining to the study included the study design, the adjustment applied to the outcome variables (risk ratio; RR, hazard ratio; HR, odds ratio; OR, and standardised incidence rate; SIR).

\section{Outcome}

Overall and specific cancer risk analyzed by each study and the number of subjects who developed each kind of cancer were extracted. We used the unadjusted RR as the common outcome measurement for comparison between all studies. If only adjusted RRs or adjusted or unadjusted ORs were reported, unadjusted RR values were manually calculated.

Unadjusted HRs and SIRs were considered interchangeable with the unadjusted RR [68]. If studies reported only adjusted HRs, effort was invested to contact the authors to obtain the unadjusted values. For conversion of adjusted RRs and adjusted ORs to unadjusted RRs, and for ACR computation, we contacted the authors of the studies to determine if the number of cases of subsequent cancer in PD patients and control subjects were reported.

Of the fourteen papers, three provided adjusted HRs $[64,69,70]$, two provided unadjusted SIRs $[4,19]$, one provided unadjusted ORs [15], three provided adjusted RRs $[20,71,72]$, while five provided adjusted ORs [14, 73-76]. Of the studies reporting adjusted RRs and adjusted ORs, only one author [14] was able to supplement with unadjusted ORs. Other authors were unable to assist in our analysis due to a lack of access or unavailability of study data.

\section{Assessment of study quality}

The risk of bias (RoB) analysis was conducted using the Newcastle-Ottawa Scale (NOS). NOS scores were subsequently converted to Agency for Healthcare Research and Quality (AHRQ) ratings to classify the studies as of 'Good', 'Fair' or 'Poor' quality. The RoB and AHQR framework used for study assessment in this meta-analysis are detailed in Supplementary Methods. Two reviewers (J.Y.S.L and J.H.N) assessed the quality of all included studies and discussed discrepancies until consensus was reached. The risk of bias analysis for cohort and case-control studies are detailed in Supplementary Table 5A and 5B respectively.

\section{Subgroup analyses}

Besides analyzing the relationship between PD and the risk of subsequent cancer in general, and that of specific cancers through the primary and subgroup analysis, secondary analyses were conducted. These subgroup 
analyses investigated the effect of genetic variants implicated in PD development, PD treatment, and gender on subsequent cancer development. Studies included in these subgroup analyses were identified during the database search but did not meet the inclusion criteria for primary analysis. We conducted subgroup analyses using these studies since both cancer and PD are multifactorial. Similar variables were extracted for the secondary analyses as for the primary analyses. Details and results of the studies included are provided in the subsequent sections.

\section{Statistical analysis}

Review Manager (Review Manager (RevMan) [Computer program]. Version 5.4. The Cochrane Collaboration, 2020) was used for data analysis in the present study. Type I error was fixed at 5\% and 95\% confidence intervals were reported for all calculations.

\section{Heterogeneity between studies}

Heterogeneity between the studies was evaluated using the $Q$ test and $\mathrm{I}^{2}$. $P$ values for the $\mathrm{I}^{2}$ statistics were computed by chi-square distribution of Cochran $Q$ test. Random effect models were used to pool the results and to allow for differences in the treatment effect from study to study (sampling variability across studies). Subgroup analyses on PD's effect on subsequent development of specific cancers were conducted to assess the heterogeneity source.

\section{Sensitivity analysis}

Sensitivity analysis was conducted to assess the robustness of the present study. The meta-analysis was conducted twice, once with all studies included, and once after excluding studies rated 'Poor' by AHRQ standards for sensitivity analysis.

\section{Publication bias}

Publication bias of the included studies was assessed using the funnel plot (Supplementary Figure 1A-1C).

\section{Abbreviations}

PD: Parkinson's Disease; QUOROM: Quality of Reporting of Meta-analyses; CNS: Central nervous system; LRRK2: Leucine-rich repeat kinase 2; LRRK2G2019S PD: PD patients with LRRK2-G2019S gene mutation; UCH-L1: Ubiquitin carboxyl-terminal hydrolase L1; NS: Novelty-seeking; HA: Harm avoidance; TMN: 2,3,6-trimethyl-1,4-napthoquinone; MAO: Monoamine oxidase; MPTP: 1-methyl-4-phenyl1,2,3,6-tetrahydropyridine; SCFA: Short chain fatty acids; UV: Ultraviolet; RR: Risk ratio; OR: Odds ratio; SIR: Standardised incidence ratio; HR: Hazard ratio; CI: Confidence interval; RoB: Risk of Bias; NOS:
Newcastle-Ottawa Scale; AHRQ: Agency for Healthcare and Research Quality.

\section{AUTHOR CONTRIBUTIONS}

Joon Yan Selene Lee extracted and analysed the relevant data and contributed substantially to the drafting of the manuscript. Eng-King Tan provided clinical expertise and advice and was involved in editing the manuscript. Seyed Ehsan Saffari contributed to the statistical analysis of the extracted data. Jing Han $\mathrm{Ng}$ was involved in the review of the manuscript. All authors confirm the final version of the manuscript and contributed to the write-up.

\section{ACKNOWLEDGMENTS}

We thank the National Medical Research Council for support (STaR and PD LCG 0002 grants) and Dr Agalliu of Albert Einstein College of Medicine, NY, USA, for providing relevant data included in this metaanalysis.

\section{CONFLICTS OF INTEREST}

The authors declare no conflicts of interest related to this study.

\section{FUNDING}

This work was supported by the National Medical Research Council.

\section{REFERENCES}

1. Jankovic J, Tan EK. Parkinson's disease: etiopathogenesis and treatment. J Neurol Neurosurg Psychiatry. 2020; 91:795-808. https://doi.org/10.1136/innp-2019-322338 PMID: $\underline{32576618}$

2. Epidemiology \& Disease Control Division, Ministry of Health, Singapore, and Institute for Health Metrics and Evaluation. The Burden of Disease in Singapore, 1990-2017: An overview of the Global Burden of Disease Study 2017 results. Seattle, WA: IHME. 2019. https://www.moh.gov.sg/docs/librariesprovider5/def ault-document-

library/gbd 2017 singapore reportce6bb0b3ad1a49 c19ee6ebadc1273b18.pdf

3. Constantinescu R, Romer $\mathrm{M}$, Kieburtz $\mathrm{K}$, and DATATOP Investigators of the Parkinson Study Group. Malignant melanoma in early Parkinson's disease: the DATATOP trial. Mov Disord. 2007; 22:720-2.

https://doi.org/10.1002/mds.21273

PMID: 17373726 
4. Rugbjerg K, Friis S, Lassen CF, Ritz B, Olsen JH. Malignant melanoma, breast cancer and other cancers in patients with Parkinson's disease. Int J Cancer. 2012; 131:1904-11.

https://doi.org/10.1002/ijc.27443

PMID:22278152

5. Fiala KH, Whetteckey J, Manyam BV. Malignant melanoma and levodopa in Parkinson's disease: causality or coincidence? Parkinsonism Relat Disord. 2003; 9:321-7. https://doi.org/10.1016/s1353-8020(03)00040-3 PMID:12853231

6. Sun LM, Liang JA, Chang SN, Sung FC, Muo $\mathrm{CH}$, Kao $\mathrm{CH}$. Analysis of Parkinson's disease and subsequent cancer risk in Taiwan: a nationwide population-based cohort study. Neuroepidemiology. 2011; 37:114-9. https://doi.org/10.1159/000331489 PMID:21986194

7. Sandyk R. Accelerated growth of malignant melanoma by levodopa in Parkinson's disease and role of the pineal gland. Int J Neurosci. 1992; 63:137-40. https://doi.org/10.3109/00207459208986663 PMID: 1342025

8. Olsen JH, Friis S, Frederiksen K. Malignant melanoma and other types of cancer preceding Parkinson disease. Epidemiology. 2006; 17:582-7. https://doi.org/10.1097/01.ede.0000229445.90471.5e PMID: 16837822

9. Tang CF, Lu MK, Muo CH, Tsai CH, Kao CH. Increased risk of brain tumor in patients with Parkinson's disease: a nationwide cohort study in Taiwan. Acta Neurol Scand. 2016; 134:148-53.

https://doi.org/10.1111/ane.12524 PMID:26508469

10. Driver JA, Logroscino G, Buring JE, Gaziano JM, Kurth T. A prospective cohort study of cancer incidence following the diagnosis of Parkinson's disease. Cancer Epidemiol Biomarkers Prev. 2007; 16:1260-5. https://doi.org/10.1158/1055-9965.epi-07-0038 PMID: 17548694

11. Bose A, Petsko GA, Eliezer D. Parkinson's Disease and Melanoma: Co-Occurrence and Mechanisms. J Parkinsons Dis. 2018; 8:385-98.

https://doi.org/10.3233/JPD-171263

PMID:29991141

12. Gieseler F, Gaertner L, Thaden E, Theobald W. Cancer Diagnosis: A Trauma for Patients and Doctors Alike. Oncologist. 2018; 23:752-4.

https://doi.org/10.1634/theoncologist.2017-0478 PMID:29472311

13. Saunders-Pullman R, Barrett MJ, Stanley KM, Luciano MS, Shanker V, Severt L, Hunt A, Raymond D, Ozelius
LJ, Bressman SB. LRRK2 G2019S mutations are associated with an increased cancer risk in Parkinson disease. Mov Disord. 2010; 25:2536-41.

https://doi.org/10.1002/mds.23314

PMID:20818610

14. Agalliu I, Ortega RA, Luciano MS, Mirelman A, PontSunyer C, Brockmann K, Vilas D, Tolosa E, Berg D, Warø B, Glickman A, Raymond D, Inzelberg R, et al. Cancer outcomes among Parkinson's disease patients with leucine rich repeat kinase 2 mutations, idiopathic Parkinson's disease patients, and nonaffected controls. Mov Disord. 2019; 34:1392-8.

https://doi.org/10.1002/mds.27807

PMID: $\underline{31348549}$

15. Ruiz-Martínez J, de la Riva $P$, Rodríguez-Oroz $M C$, Mondragón Rezola E, Bergareche A, Gorostidi A, Gago B, Estanga A, Larrañaga N, Sarasqueta C, López de Munain A, Martí Massó JF. Prevalence of cancer in Parkinson's disease related to R1441G and G2019S mutations in LRRK2. Mov Disord. 2014; 29:750-5.

https://doi.org/10.1002/mds.25778

PMID:24357540

16. Agalliu I, San Luciano M, Mirelman A, Giladi N, Waro B, Aasly J, Inzelberg R, Hassin-Baer S, Friedman E, Ruiz-Martinez J, Marti-Masso JF, Orr-Urtreger A, Bressman S, Saunders-Pullman R. Higher frequency of certain cancers in LRRK2 G2019S mutation carriers with Parkinson disease: a pooled analysis. JAMA Neurol. 2015; 72:58-65.

https://doi.org/10.1001/jamaneurol.2014.1973 PMID:25401981

17. Inzelberg R, Cohen OS, Aharon-Peretz J, Schlesinger I, Gershoni-Baruch R, Djaldetti R, Nitsan Z, Ephraty L, Tunkel O, Kozlova E, Inzelberg L, Kaplan N, Fixler Mehr T, et al. The LRRK2 G2019S mutation is associated with Parkinson disease and concomitant non-skin cancers. Neurology. 2012; 78:781-6. https://doi.org/10.1212/WNL.0b013e318249f673 PMID:22323743

18. Warø BJ, Aasly JO. Exploring cancer in LRRK2 mutation carriers and idiopathic Parkinson's disease. Brain Behav. 2017; 8:e00858.

https://doi.org/10.1002/brb3.858 PMID:29568677

19. Peretz C, Gurel R, Rozani V, Gurevich T, El-Ad B, Tsamir J, Giladi N. Cancer incidence among Parkinson's disease patients in a 10-yrs time-window around disease onset: A large-scale cohort study. Parkinsonism Relat Disord. 2016; 28:68-72. https://doi.org/10.1016/i.parkreldis.2016.04.028 PMID:27161827

20. Ong EL, Goldacre R, Goldacre M. Differential risks of cancer types in people with Parkinson's disease: a 
national record-linkage study. Eur J Cancer. 2014; 50:2456-62.

https://doi.org/10.1016/j.ejca.2014.06.018

PMID:25065294

21. Ritz B, Ascherio A, Checkoway H, Marder KS, Nelson LM, Rocca WA, Ross GW, Strickland D, Van Den Eeden SK, Gorell J. Pooled analysis of tobacco use and risk of Parkinson disease. Arch Neurol. 2007; 64:990-7. https://doi.org/10.1001/archneur.64.7.990 PMID:17620489

22. Inzelberg R, Rabey JM, Melamed E, Djaldetti R, Reches A, Badarny S, Hassin-Baer S, Cohen O, Trau H, Aharon-Peretz J, Milo R, Schwartz M, Huberman M, et al. High prevalence of malignant melanoma in Israeli patients with Parkinson's disease. J Neural Transm (Vienna). 2011; 118:1199-207. https://doi.org/10.1007/s00702-011-0580-2 PMID:21298300

23. D'Amelio M, Ragonese P, Sconzo G, Aridon P, Savettieri G. Parkinson's disease and cancer: insights for pathogenesis from epidemiology. Ann N Y Acad Sci. 2009; 1155:324-34. https://doi.org/10.1111/i.1749-6632.2008.03681.x PMID:19250224

24. Gaillard H, García-Muse T, Aguilera A. Replication stress and cancer. Nat Rev Cancer. 2015; 15:276-89. https://doi.org/10.1038/nrc3916 PMID:25907220

25. Poletti M, Bonuccelli U. Personality traits in patients with Parkinson's disease: assessment and clinical implications. J Neurol. 2012; 259:1029-38.

https://doi.org/10.1007/s00415-011-6302-8 PMID:22083431

26. LoConte NK, Gershenwald JE, Thomson CA, Crane TE, Harmon GE, Rechis R. Lifestyle Modifications and Policy Implications for Primary and Secondary Cancer Prevention: Diet, Exercise, Sun Safety, and Alcohol Reduction. Am Soc Clin Oncol Educ Book. 2018; 38:88-100.

https://doi.org/10.1200/EDBK 200093 PMID:30231343

27. Csoti I, Jost WH, Reichmann H. Parkinson's disease between internal medicine and neurology. J Neural Transm (Vienna). 2016; 123:3-17. https://doi.org/10.1007/s00702-015-1443-z PMID:26298728

28. Bovolenta TM, de Azevedo Silva SM, Arb Saba R, Borges V, Ferraz HB, Felicio AC. Systematic Review and Critical Analysis of Cost Studies Associated with Parkinson's Disease. Parkinsons Dis. 2017; 2017:3410946. https://doi.org/10.1155/2017/3410946 PMID:28357150
29. Mantri S, Fullard ME, Beck J, Willis AW. State-level prevalence, health service use, and spending vary widely among Medicare beneficiaries with Parkinson disease. NPJ Parkinsons Dis. 2019; 5:1.

https://doi.org/10.1038/s41531-019-0074-8

PMID: 30701188

30. Gallo V, Vineis P, Cancellieri M, Chiodini P, Barker RA, Brayne C, Pearce N, Vermeulen R, Panico S, Buenode-Mesquita B, Vanacore N, Forsgren L, Ramat S, et al. Exploring causality of the association between smoking and Parkinson's disease. Int J Epidemiol. 2019; 48:912-25.

https://doi.org/10.1093/ije/dyy230

PMID: $\underline{30462234}$

31. Mehrian-Shai R, Reichardt JKV, Harris CC, Toren A. The Gut-Brain Axis, Paving the Way to Brain Cancer. Trends Cancer. 2019; 5:200-7.

https://doi.org/10.1016/i.trecan.2019.02.008 PMID: $\underline{30961828}$

32. Bullich C, Keshavarzian A, Garssen J, Kraneveld A, Perez-Pardo P. Gut Vibes in Parkinson's Disease: The Microbiota-Gut-Brain Axis. Mov Disord Clin Pract. 2019; 6:639-51.

https://doi.org/10.1002/mdc3.12840

PMID: 31745471

33. Boulos C, Yaghi N, El Hayeck R, Heraoui GN, FakhourySayegh N. Nutritional Risk Factors, Microbiota and Parkinson's Disease: What Is the Current Evidence? Nutrients. 2019; 11:1896.

https://doi.org/10.3390/nu11081896

PMID: $\underline{1416163}$

34. Ye $\mathrm{Q}$, Wen $\mathrm{Y}$, Al-Kuwari N, Chen X. Association Between Parkinson's Disease and Melanoma: Putting the Pieces Together. Front Aging Neurosci. 2020; 12:60.

https://doi.org/10.3389/fnagi.2020.00060

PMID: $\underline{2210791}$

35. Li JQ, Tan L, Yu JT. The role of the LRRK2 gene in Parkinsonism. Mol Neurodegener. 2014; 9:47. https://doi.org/10.1186/1750-1326-9-47 PMID:25391693

36. Giampazolias E, Tait SW. Mitochondria and the hallmarks of cancer. FEBS J. 2016; 283:803-14.

https://doi.org/10.1111/febs.13603 PMID:26607558

37. Manzoni C. The LRRK2-macroautophagy axis and its relevance to Parkinson's disease. Biochem Soc Trans. 2017; 45:155-62.

https://doi.org/10.1042/BST20160265 PMID:28202669

38. Padmanabhan S, Lanz TA, Gorman D, Wolfe M, Joyce A, Cabrera C, Lawrence-Henderson R, Levers N, Joshi 
N, Ma TC, Liong C, Narayan S, Alcalay RN, et al. An Assessment of LRRK2 Serine 935 Phosphorylation in Human Peripheral Blood Mononuclear Cells in Idiopathic Parkinson's Disease and G2019S LRRK2 Cohorts. J Parkinsons Dis. 2020; 10:623-9.

https://doi.org/10.3233/JPD-191786 PMID:32007961

39. Maekawa T, Shimayama H, Tsushima H, Kawakami F, Kawashima $R$, Kubo $M$, Ichikawa T. LRRK2: An Emerging New Molecule in the Enteric Neuronal System That Quantitatively Regulates Neuronal Peptides and IgA in the Gut. Dig Dis Sci. 2017; 62:903-12.

https://doi.org/10.1007/s10620-017-4476-3 PMID:28168579

40. Jung K, Choi JS, Koo BM, Kim YJ, Song JY, Sung M, Chang ES, Noh KW, An S, Lee MS, Song K, Lee H, Kim RN, et al. TM4SF4 and LRRK2 Are Potential Therapeutic Targets in Lung and Breast Cancers through Outlier Analysis. Cancer Res Treat. 2021; 53:9-24.

https://doi.org/10.4143/crt.2020.434

PMID:32972043

41. Yang C, Pang J, Xu J, Pan H, Li Y, Zhang H, Liu H, Xiao SY. LRRK2 is a candidate prognostic biomarker for clear cell renal cell carcinoma. Cancer Cell Int. 2021; 21:343.

https://doi.org/10.1186/s12935-021-02047-y PMID:34217264

42. Cheung M, Kadariya $Y$, Sementino E, Hall MJ, Cozzi I, Ascoli V, Ohar JA, Testa JR. Novel LRRK2 mutations and other rare, non-BAP1-related candidate tumor predisposition gene variants in high-risk cancer families with mesothelioma and other tumors. Hum Mol Genet. 2021; 30:1750-61.

https://doi.org/10.1093/hmg/ddab138

PMID: $\underline{34008015}$

43. Zhang L, Han $L$, Huang $Y$, Feng $Z$, Wang $X$, Li H, Song $F$, Liu L, Li J, Zheng $H$, Wang $P$, Song $F$, Chen K. SNPs within microRNA binding sites and the prognosis of breast cancer. Aging (Albany NY). 2021; 13:7465-80. https://doi.org/10.18632/aging.202612 PMID:33658398

44. Chen L, Hou J, Zeng X, Guo Q, Deng M, Kloeber JA, Tu $X$, Zhao F, Wu Z, Huang J, Luo K, Kim W, Lou Z. LRRK2 inhibition potentiates PARP inhibitor cytotoxicity through inhibiting homologous recombinationmediated DNA double strand break repair. Clin TransI Med. 2021; 11:e341. https://doi.org/10.1002/ctm2.341 PMID:33784003

45. Chen Z, Cao Z, Zhang W, Gu M, Zhou ZD, Li B, Li J, Tan EK, Zeng L. LRRK2 interacts with ATM and regulates
Mdm2-p53 cell proliferation axis in response to genotoxic stress. Hum Mol Genet. 2017; 26:4494-505. https://doi.org/10.1093/hmg/ddx337

PMID:28973420

46. Cerri S, Mus L, Blandini F. Parkinson's Disease in Women and Men: What's the Difference? J Parkinsons Dis. 2019; 9:501-15. https://doi.org/10.3233/JPD-191683 PMID:31282427

47. Mauvais-Jarvis F, Clegg DJ, Hevener AL. The role of estrogens in control of energy balance and glucose homeostasis. Endocr Rev. 2013; 34:309-38. https://doi.org/10.1210/er.2012-1055 PMID:23460719

48. Lee YH, Cha J, Chung SJ, Yoo HS, Sohn YH, Ye BS, Lee $\mathrm{PH}$. Beneficial effect of estrogen on nigrostriatal dopaminergic neurons in drug-naïve postmenopausal Parkinson's disease. Sci Rep. 2019; 9:10531. https://doi.org/10.1038/s41598-019-47026-6 PMID: $\underline{31324895}$

49. Bajaj A, Driver JA, Schernhammer ES. Parkinson's disease and cancer risk: a systematic review and metaanalysis. Cancer Causes Control. 2010; 21:697-707. https://doi.org/10.1007/s10552-009-9497-6 PMID:20054708

50. Zhang $P$, Liu B. Association between Parkinson's Disease and Risk of Cancer: A PRISMA-compliant Meta-analysis. ACS Chem Neurosci. 2019; 10:4430-9. https://doi.org/10.1021/acschemneuro.9b00498 PMID: $\underline{31584793}$

51. GBD 2016 Parkinson's Disease Collaborators. Global, regional, and national burden of Parkinson's disease, 1990-2016: a systematic analysis for the Global Burden of Disease Study 2016. Lancet Neurol. 2018; 17:939-53.

https://doi.org/10.1016/S1474-4422(18)30295-3 PMID:30287051

52. Bray F, Ferlay J, Soerjomataram I, Siegel RL, Torre LA, Jemal A. Global cancer statistics 2018: GLOBOCAN estimates of incidence and mortality worldwide for 36 cancers in 185 countries. CA Cancer J Clin. 2018; 68:394-424.

https://doi.org/10.3322/caac.21492

PMID:30207593

53. Schwid SR, Bausch J, Oakes D, Schuchter L, Tanner C, Forrest M, Lang AE, Shoulson I, Shoulson I, Hyson C, Oakes D, Flagg E, Rudolph A, et al, and PSG PRECEPT Investigators. Cancer incidence in a trial of an antiapoptotic agent for Parkinson's disease. Mov Disord. 2010; 25:1801-8.

https://doi.org/10.1002/mds.23006

PMID:20669311 
54. Wang V, Chao TH, Hsieh CC, Lin CC, Kao CH. Cancer risks among the users of ergot-derived dopamine agonists for Parkinson's disease, a nationwide population-based survey. Parkinsonism Relat Disord. 2015; 21:18-22.

https://doi.org/10.1016/j.parkreldis.2014.10.015 PMID:25457814

55. Korhonen $\mathrm{P}$, Kuoppamäki $\mathrm{M}$, Prami $\mathrm{T}$, Hoti $\mathrm{F}$, Christopher S, Ellmén J, Aho V, Vahteristo M, Pukkala E, Haukka J. Entacapone and prostate cancer risk in patients with Parkinson's disease. Mov Disord. 2015; 30:724-8. https://doi.org/10.1002/mds.26140 PMID:25639262

56. Bertoni JM, Arlette JP, Fernandez HH, Fitzer-Attas C, Frei $\mathrm{K}$, Hassan MN, Isaacson SH, Lew MF, Molho E, Ondo WG, Phillips TJ, Singer C, Sutton JP, Wolf JE Jr, and North American Parkinson's and Melanoma Survey Investigators. Increased melanoma risk in Parkinson disease: a prospective clinicopathological study. Arch Neurol. 2010; 67:347-52.

https://doi.org/10.1001/archneurol.2010.1 PMID:20212233

57. Constantinescu R, Elm J, Auinger $P$, Sharma $S$, Augustine EF, Khadim L, Kieburtz K, and NET-PD Investigators. Malignant melanoma in early-treated Parkinson's disease: the NET-PD trial. Mov Disord. 2014; 29:263-5.

https://doi.org/10.1002/mds.25734

PMID:24323565

58. Boursi B, Mamtani R, Haynes K, Yang YX. Parkinson's disease and colorectal cancer risk-A nested case control study. Cancer Epidemiol. 2016; 43:9-14. https://doi.org/10.1016/j.canep.2016.05.007 PMID:27232063

59. Major JM, Dong D, Cunningham F, By K, Hur K, Shih DC, Jiang R, Podskalny GD, Wei X, Pinheiro S, Bird ST, Keeton S, Graham DJ. Entacapone and prostate cancer in Parkinson's disease patients: A large Veterans Affairs healthcare system study. Parkinsonism Relat Disord. 2018; 53:46-52. https://doi.org/10.1016/j.parkreldis.2018.04.035 PMID:29759929

60. Allegra R, Tunesi S, Cilia R, Pezzoli G, Goldwurm S. LRRK2-G2019S mutation is not associated with an increased cancer risk: a kin-cohort study. Mov Disord. 2014; 29:1325-6. https://doi.org/10.1002/mds.25969 PMID:25048644

61. Ryu HJ, Park JH, Choi M, Jung JH, Han K, Kwon DY, Kim $\mathrm{DH}$, Park YG. Parkinson's disease and skin cancer risk: a nationwide population-based cohort study in Korea. J Eur Acad Dermatol Venereol. 2020; 34:2775-80. https://doi.org/10.1111/jdv.16462

PMID:32289877

62. Jespersen CG, Nørgaard M, Borre M. Parkinson's disease and risk of prostate cancer: A Danish population-based case-control study, 1995-2010. Cancer Epidemiol. 2016; 45:157-61. https://doi.org/10.1016/j.canep.2016.11.002 PMID:27838564

63. Kareus SA, Figueroa KP, Cannon-Albright LA, Pulst SM. Shared predispositions of parkinsonism and cancer: a population-based pedigree-linked study. Arch Neurol. 2012; 69:1572-7.

https://doi.org/10.1001/archneurol.2012.2261 PMID:22945795

64. Lin PY, Chang SN, Hsiao TH, Huang BT, Lin CH, Yang PC. Association Between Parkinson Disease and Risk of Cancer in Taiwan. JAMA Oncol. 2015; 1:633-40.

https://doi.org/10.1001/jamaoncol.2015.1752 PMID:26181771

65. Liao KF, Lin CL, Lai SW, Chen WC. Parkinson's disease and risk of pancreatic cancer: a population-based case-control study in Taiwan. Neurol Asia. 2015; 20:251-5.

66. Lerman S, Amichai B, Weinstein G, Shalev V, Chodick G. Parkinson's Disease, Melanoma, and Keratinocyte Carcinoma: A Population-Based Study. Neuroepidemiology. 2018; 50:168-73.

https://doi.org/10.1159/000487855

PMID:29566384

67. Peryer G, Golder S, Junqueira DR, Vohra S, Loke YK. Chapter 19: Adverse effects. Cochrane Training. 2021. https://training.cochrane.org/handbook/current/cha pter-19.

68. Higgins JPT, Li T, Deeks JJ. Chapter 6: Choosing effect measures and computing estimates of effect. Cochrane Training. 2021. https://training.cochrane.org/ handbook/current/chapter-06.

69. Park JH, Kim DH, Park YG, Kwon DY, Choi M, Jung JH, Han K. Cancer risk in patients with Parkinson's disease in South Korea: A nationwide, population-based cohort study. Eur J Cancer. 2019; 117:5-13. https://doi.org/10.1016/j.ejca.2019.04.033 PMID: $\underline{31229950}$

70. Wirdefeldt $\mathrm{K}$, Weibull CE, Chen $\mathrm{H}$, Kamel F, Lundholm C, Fang F, Ye W. Parkinson's disease and cancer: A register-based family study. Am J Epidemiol. 2014; 179:85-94.

https://doi.org/10.1093/aje/kwt232 PMID:24142916

71. Fois $A F$, Wotton CJ, Yeates D, Turner MR, Goldacre MJ. Cancer in patients with motor neuron disease, 
multiple sclerosis and Parkinson's disease: record linkage studies. J Neurol Neurosurg Psychiatry. 2010; 81:215-21.

https://doi.org/10.1136/innp.2009.175463

PMID:19726405

72. Lo RY, Tanner CM, Van Den Eeden SK, Albers KB, Leimpeter AD, Nelson LM. Comorbid cancer in Parkinson's disease. Mov Disord. 2010; 25:1809-17. https://doi.org/10.1002/mds.23246 PMID:20669266

73. Freedman DM, Wu J, Chen $\mathrm{H}$, Kuncl RW, Enewold LR, Engels EA, Freedman ND, Pfeiffer RM. Associations between cancer and Alzheimer's disease in a U.S. Medicare population. Cancer Med. 2016; 5:2965-76. https://doi.org/10.1002/cam4.850 PMID:27628596

74. Tacik $P$, Curry S, Fujioka S, Strongosky A, Uitti RJ, van Gerpen JA, Diehl NN, Heckman MG, Wszolek ZK. Cancer in Parkinson's disease. Parkinsonism Relat Disord. 2016; 31:28-33.

https://doi.org/10.1016/j.parkreldis.2016.06.014 PMID:27372241
75. Shalaby SY, Louis ED. Statin Use and Its Association with Essential Tremor and Parkinson's Disease. Neuroepidemiology. 2016; 47:11-7.

https://doi.org/10.1159/000446655

PMID:27304858

76. Becker C, Brobert GP, Johansson S, Jick SS, Meier CR. Cancer risk in association with Parkinson disease: a population-based study. Parkinsonism Relat Disord. 2010; 16:186-90.

https://doi.org/10.1016/j.parkreldis.2009.11.005

PMID:19945903 


\section{SUPPLEMENTARY MATERIALS}

\section{Supplementary Methods}

\section{Database search strategy}

Pubmed search - 27 August 2020

- Search chain: (((neoplasm[MeSH Terms]) OR (cancer) AND ((fft[Filter]) AND (humans[Filter]))) AND ((parkinson's) OR (parkinson's disease[MeSH Terms]) AND ((fft[Filter]) AND (humans[Filter])))) AND ((((epidemiological studies[MeSH Terms]) OR (cohort studies[MeSH Terms])) OR (case control studies[MeSH Terms])) OR (observational studies) AND ((fft[Filter]) AND (humans[Filter])))

- Date range: 2010-2020

- Number of identified results: 322

- Number of shortlisted results: 47

SCOPUS search -28 August 2020

- Search chain: ('parkinson disease'/mj OR 'parkinson disease' OR 'parkinson's disease' OR 'parkinsons disease' OR 'paralysis agitans' OR 'parkinson dementia complex' $O R$ 'parkinson disease, postencephalitic' OR 'parkinson disease, secondary' $O R$ 'parkinson disease, symptomatic') AND 'neoplasm'/mj AND ('incidence'/exp OR 'incidence' $O R$ 'incidence rate' $O R$ 'rate, incidence' OR 'prevalence'/exp)

- Date range: 2010-2020

Web of Science search - 30 August 2020

- Search chain:

Step 1: Cancer (Topic)

Step 2: Parkinson's disease (Topic)

Step 3: Epidemiological study (Topic)

- Search: 1 AND 2 AND 3

- Filters: English

- Date range: 2010-2020
Risk of bias (RoB) analysis using the Newcastle Ottawa Scale

The Newcastle Ottawa Scale (NOS) assesses study quality using a 9-point scale broadly divided into the following three categories:

a. Study selection -4 points

b. Comparability -2 points

c. Exposure -3 points.

The detailed criteria for RoB analysis using the NOS scale for case-control and cohort studies are detailed elsewhere.

Subsequent conversion of NOS scores to Agency for Healthcare Research and Quality (AHRQ) standards was done classify the studies as being 'Good', 'Fair' or 'Poor' quality, based on the following criteria:

a. Good -3 or 4 stars in selection domain AND 1 or 2 stars in comparability domain AND 2 or 3 stars in outcome/exposure domain.

b. Fair -2 stars in selection domain AND 1 or 2 stars in comparability domain AND 2 or 3 stars in outcome/exposure domain.

c. Poor -0 or 1 star in selection domain OR 0 stars in comparability domain OR 0 or 1 stars in outcome/exposure domain. 


\section{Supplementary Figure}
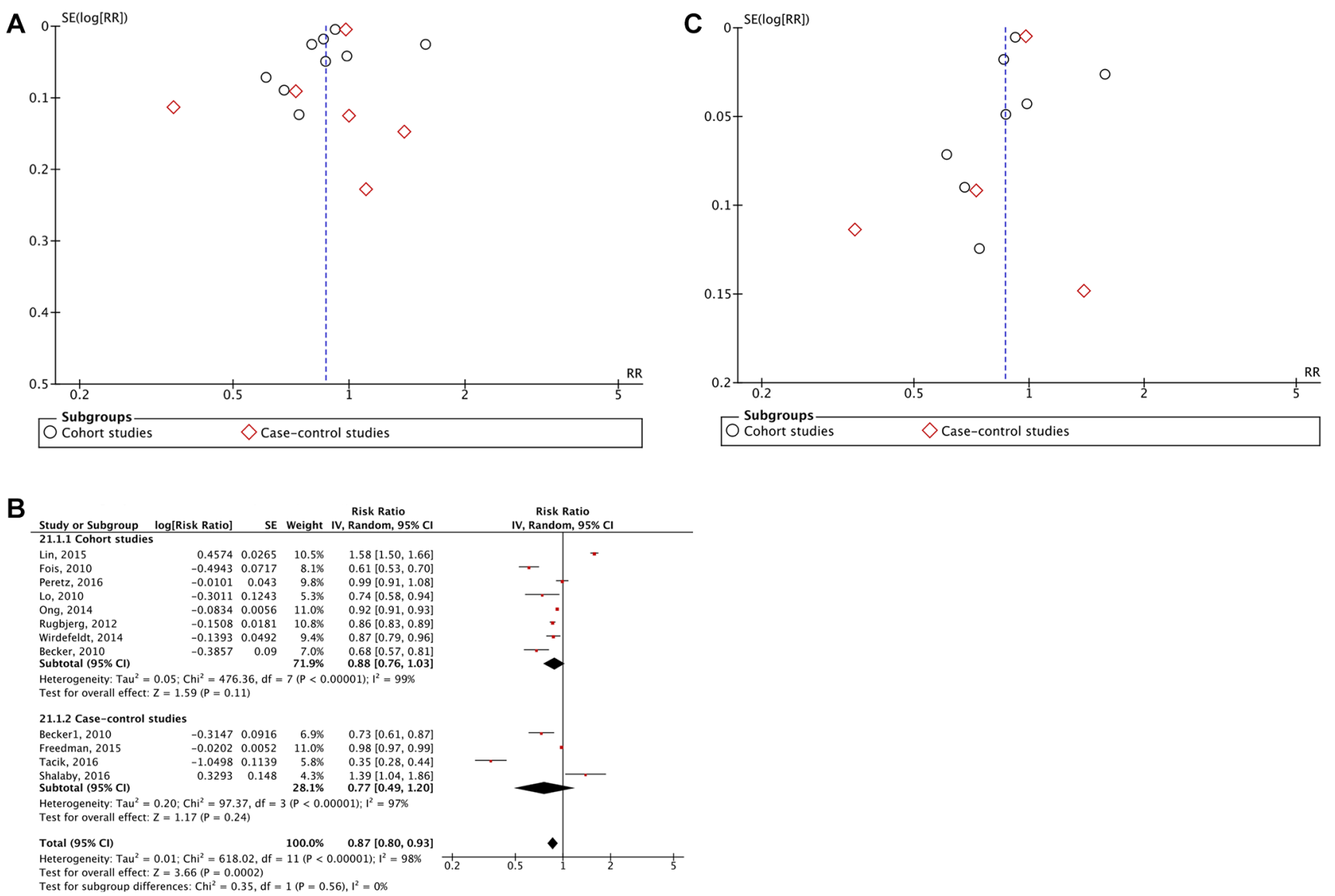

Supplementary Figure 1. (A) Funnel plot for assessment of publication bias in the included studies before sensitivity analysis. (B) Forest plot of the association between PD and relative risk of cancer in general, after sensitivity analysis. (C) Funnel plot of included studies after sensitivity analysis. 


\section{Supplementary Tables}

\section{Supplementary Table 1. QUOROM Statement checklist.}

\begin{tabular}{|c|c|c|c|c|}
\hline Heading & Subheading & Descriptor & $\begin{array}{l}\text { Reported? } \\
(\mathbf{Y} / \mathbf{N})\end{array}$ & $\begin{array}{l}\text { Page } \\
\text { Number }\end{array}$ \\
\hline Title & & Identify the report as a systematic review & Y & 1 \\
\hline \multirow[t]{7}{*}{ Abstract } & & Use a structured format & $\mathrm{Y}$ & 2 \\
\hline & Objectives & The clinical question explicitly & Y & 2 \\
\hline & Data sources & The databases (i.e., list) and other information sources & Y & 2 \\
\hline & Review methods & $\begin{array}{l}\text { The selection criteria (i.e., population, intervention, outcome, and } \\
\text { study design); methods for validity assessment, data abstraction, and } \\
\text { study characteristics, and quantitative data synthesis in sufficient } \\
\text { detail to permit replication }\end{array}$ & $\mathrm{Y}$ & 2 \\
\hline & Results & $\begin{array}{l}\text { Characteristics of the RCTs included and excluded; qualitative and } \\
\text { quantitative findings (i.e., point estimates and confidence intervals); } \\
\text { and subgroup analyses }\end{array}$ & Y & 2 \\
\hline & Conclusion & The main results & $\mathrm{Y}$ & 2 \\
\hline & & Describe & & \\
\hline Introduction & & $\begin{array}{l}\text { The explicit clinical problem, biological rationale for the } \\
\text { intervention, and rationale for review }\end{array}$ & $\mathrm{Y}$ & $3-4$ \\
\hline \multirow[t]{6}{*}{ Methods } & Searching & $\begin{array}{l}\text { The information sources, in detail (e.g., databases, registers, personal } \\
\text { files, expert informants, agencies, hand-searching), and any } \\
\text { restrictions (years considered, publication status, language of } \\
\text { publication) }\end{array}$ & $\mathrm{Y}$ & 17 \\
\hline & Selection & $\begin{array}{l}\text { The inclusion and exclusion criteria (defining population, } \\
\text { intervention, principal outcomes, and study design }\end{array}$ & Y & $17-18$ \\
\hline & Validity assessment & $\begin{array}{l}\text { The criteria and process used (e.g., masked conditions, quality } \\
\text { assessment, and their findings) }\end{array}$ & Y & $17-18$ \\
\hline & Data abstraction & $\begin{array}{l}\text { The process or processes used (e.g., completed independently, in } \\
\text { duplicate) }\end{array}$ & Y & 17 \\
\hline & Study characteristics & $\begin{array}{l}\text { The type of study design, participants' characteristics, details of } \\
\text { intervention, outcome definitions, and how clinical heterogeneity } \\
\text { was assessed }\end{array}$ & Y & 19 \\
\hline & Quantitative data synthesis & $\begin{array}{l}\text { The principal measures of effect (e.g., relative risk), method of } \\
\text { combining results (statistical testing and confidence intervals), } \\
\text { handling of missing data; how statistical heterogeneity was assessed; } \\
\text { a rationale for any a-priori sensitivity and subgroup analyses; and any } \\
\text { assessment of publication bias }\end{array}$ & $\mathrm{Y}$ & $20-21$ \\
\hline \multirow[t]{3}{*}{ Results } & Trial flow & Provide a meta-analysis profile summarising trial flow (see figure) & Y & $7-10$ \\
\hline & Study characteristics & $\begin{array}{l}\text { Present descriptive data for each trial (e.g., age, sample size, } \\
\text { intervention, dose, duration, follow-up period) }\end{array}$ & $\mathrm{Y}$ & $\begin{array}{l}\text { Refer to } \\
\text { Table } 1\end{array}$ \\
\hline & Quantitative data synthesis & $\begin{array}{l}\text { Report agreement on the selection and validity assessment; present } \\
\text { simple summary results (for each treatment group in each trial, for } \\
\text { each primary outcome); present data needed to calculate effect sizes } \\
\text { and confidence intervals in intention-to-treat analyses (e.g., 2X2 } \\
\text { tables of counts, means and SDs, proportions) }\end{array}$ & $\mathrm{Y}$ & $\begin{array}{l}\text { Refer to } \\
\text { Table } 1\end{array}$ \\
\hline Discussion & & Summarise key findings; discuss clinical inferences based on internal & $\mathrm{Y}$ & $7-16$ \\
\hline
\end{tabular}


and external validity; interpret the results in light of the totality of available evidence; describe potential biases in the review process

(e.g., publication bias); and suggest a future research agenda

Supplementary Table 2. Papers excluded from primary analysis and the reasons for exclusion.

\begin{tabular}{ll}
\hline First author & \multicolumn{1}{c}{ Reasons for rejection } \\
\hline Sun, 2011 & $\begin{array}{l}\text { Overlapping database and time period, smaller group of patients and controls, fewer number of } \\
\text { cancers studied compared to Lin (2015) }\end{array}$ \\
Tang, 2016 & Overlapping database and time period, fewer number of cancers studied compared to Lin (2015) \\
Liao, 2015 & Overlapping database and time period, fewer number of cancers studied compared to Lin (2015) \\
Lerman, 2018 & Overlapping database and time period, fewer number of cancers studied compared to Peretz (2016) \\
Inzelberg, 2011 & Studied impact of PD on melanoma instead of cancer in general \\
Bertoni, 2010 & Studied impact of PD on melanoma instead of cancer in general \\
Boursi, 2016 & Studied impact of PD on colorectal cancer instead of cancer in general \\
Ryu, 2020 & Studied impact of PD on skin cancer instead of cancer in general \\
Jespersen, 2016 & Studied impact of PD on prostate cancer instead of cancer in general \\
Constantinescu, 2013 & Studied impact of PD on melanoma instead of cancer in general \\
\hline
\end{tabular}

Supplementary Table 3. Characteristics of all studies included in the comparison between LRRK2-PD and idiopathic PD patients.

\begin{tabular}{|c|c|c|c|c|c|c|c|c|}
\hline No. & Author & $\begin{array}{l}\text { Study } \\
\text { design }\end{array}$ & Country & Sample size & $\begin{array}{l}\text { Females } \\
(\%)\end{array}$ & $\begin{array}{l}\text { Mean } \\
\text { age (SD) }\end{array}$ & Adjustment & Cancer (s) reported \\
\hline 1 & $\begin{array}{l}\text { Saunders- } \\
\text { Pullman, } \\
2010 \\
\end{array}$ & Cohort & USA & $\begin{array}{l}31 \text { LRRK2-PD } \\
\text { patients } \\
132 \text { iPD patients }\end{array}$ & $\begin{array}{l}75 \\
(46.0 \%)\end{array}$ & $\begin{array}{l}70.2 \\
\text { (median) }\end{array}$ & Smoking, gender & $\begin{array}{l}\text { Non-skin, renal, breast, lung, prostate, } \\
\text { haematological, reproductive }\end{array}$ \\
\hline 2 & $\begin{array}{l}\text { Agalliu, } \\
2019\end{array}$ & $\begin{array}{l}\text { Case- } \\
\text { control }\end{array}$ & $\begin{array}{l}\text { Europe, } \\
\text { Israel, } \\
\text { USA }\end{array}$ & $\begin{array}{l}257 \text { LRRK2-PD } \\
\text { patients } \\
712 \text { iPD patients } \\
218 \text { non-PD } \\
\text { controls }\end{array}$ & $\begin{array}{l}553 \\
(46.9 \%)\end{array}$ & $\begin{array}{l}67.3 \\
(10.81)\end{array}$ & $\begin{array}{l}\text { Age, sex, Ashkenazi Jews } \\
\text { ethnicity (fixed effect) and } \\
\text { study centre (random } \\
\text { effect), smoking status, } \\
\text { BMI }\end{array}$ & $\begin{array}{l}\text { Cancer in general, skin, melanoma, head } \\
\text { and neck, lung, esophageal, colon, liver, } \\
\text { pancreatic, thyroid, kidney, bladder, } \\
\text { brain, leukemia, lymphoma, hormone- } \\
\text { related, breast, ovarian, endometrial, } \\
\text { cervical, prostate, testicular }\end{array}$ \\
\hline 3 & $\begin{array}{l}\text { Warø, } \\
2018\end{array}$ & $\begin{array}{l}\text { Case- } \\
\text { control }\end{array}$ & Norway & $\begin{array}{l}103 \text { LRRK2-PD } \\
\text { patients } \\
830 \text { iPD patients }\end{array}$ & $\begin{array}{l}361 \\
(38.7 \%)\end{array}$ & $\begin{array}{l}71.2 \\
(11.6)\end{array}$ & Age, sex & $\begin{array}{l}\text { Colorectal, lung, breast, prostate, kidney, } \\
\text { bladder, thyroid, } \\
\text { lymphoma/haematologic, meningioma, } \\
\text { non-skin, others unspecified }\end{array}$ \\
\hline 4 & $\begin{array}{l}\text { Ruiz- } \\
\text { Martínez, } \\
2014\end{array}$ & $\begin{array}{l}\text { Case- } \\
\text { control }\end{array}$ & Spain & $\begin{array}{l}95 \text { LRRK2-PD } \\
\text { patients } \\
637 \text { iPD patients } \\
176 \text { non-PD } \\
\text { controls } \\
\end{array}$ & $\begin{array}{l}448 \\
(49.3)\end{array}$ & $\begin{array}{l}71.2 \\
(11.8)\end{array}$ & NR & $\begin{array}{l}\text { Cancer in general, melanoma, lung, } \\
\text { bladder, colon, kidney, breast, ovarian, } \\
\text { prostate, hormonal, haematologic, } \\
\text { meningioma, others unspecified }\end{array}$ \\
\hline 5 & $\begin{array}{l}\text { Inzelberg, } \\
2012\end{array}$ & $\begin{array}{l}\text { Case- } \\
\text { control }\end{array}$ & Israel & $\begin{array}{l}79 \text { LRRK2-PD } \\
\text { patients } \\
411 \text { iPD patients }\end{array}$ & $\begin{array}{l}191 \\
(39.0 \%)\end{array}$ & $\begin{array}{l}69.8 \\
(11.1)\end{array}$ & Age & $\begin{array}{l}\text { Cancer in general, lung, breast, prostate, } \\
\text { colon, stomach, haematologic, } \\
\text { reproductive, renal, skin, melanoma, } \\
\text { non-melanoma skin, others unspecified }\end{array}$ \\
\hline 6 & $\begin{array}{l}\text { Agalliu, } \\
2015\end{array}$ & $\begin{array}{l}\text { Case- } \\
\text { control }\end{array}$ & $\begin{array}{l}\text { Israel, } \\
\text { Norway, } \\
\text { Spain, } \\
\text { USA }\end{array}$ & $\begin{array}{l}177 \text { LRRK2-PD } \\
\text { patients } \\
1372 \text { iPD patients }\end{array}$ & $\begin{array}{l}680 \\
(43.9)\end{array}$ & $\begin{array}{l}70.9 \\
(10.8)\end{array}$ & $\begin{array}{l}\text { Adjustment (1): Age at } \\
\text { time of the first cancer } \\
\text { diagnosis, or age at the last } \\
\text { clinic visit }\end{array}$ & $\begin{array}{l}\text { Cancer in general, skin, melanoma, non- } \\
\text { skin, lung, bladder, breast, ovarian, } \\
\text { prostate, colon, kidney/renal, } \\
\text { haematologic/lymphoma, meningioma }\end{array}$ \\
\hline & & & & & & & $\begin{array}{l}\text { Adjustment (2): Age as } \\
\text { fixed effect, study centre } \\
\text { as random effect }\end{array}$ & \\
\hline & & & & & & & $\begin{array}{l}\text { Adjustment (3): Age and } \\
\text { ethnicity (Ashkenazi } \\
\text { Jewish vs. others) as fixed } \\
\text { effects and study centre as } \\
\text { random effects }\end{array}$ & \\
\hline
\end{tabular}

Abbreviations: LRRK2: Leucine-rich repeat kinase 2; iPD: Idiopathic PD; NR: Not reported. 
Supplementary Table 4. Characteristics of all studies included in the comparison between female and male patients.

\begin{tabular}{|c|c|c|c|c|c|c|c|}
\hline No. & Author & $\begin{array}{l}\text { Study } \\
\text { design }\end{array}$ & Country & $\begin{array}{l}\text { Sample size of PD } \\
\text { patients }\end{array}$ & $\begin{array}{l}\text { Mean age } \\
\text { (SD) }\end{array}$ & Adjustment & Cancer (s) reported \\
\hline 1 & $\begin{array}{l}\text { Sun, } \\
2011\end{array}$ & Cohort & Taiwan & $\begin{array}{l}2395 \text { females }(48.3 \%) \\
2562 \text { males }(51.7 \%)\end{array}$ & $63.5(20.5)$ & $\begin{array}{l}\text { Model 1: Unadjusted } \\
\text { Model 2: Adjusted for } \\
\text { age, sex, occupation } \\
\text { Model 3: Adjusted for } \\
\text { age, sex, occupation, } \\
\text { HTN, DM, } \\
\text { hyperlipidemia, heart } \\
\text { disease }\end{array}$ & Cancer in general \\
\hline 2 & $\begin{array}{l}\text { Peretz, } \\
2016\end{array}$ & Cohort & Israel & $\begin{array}{l}3297 \text { females }(46.3 \%) \\
3828 \text { males }(53.7 \%)\end{array}$ & $71.3(10.6)$ & $\begin{array}{l}\text { Age, chronological } \\
\text { year, sex }\end{array}$ & $\begin{array}{l}\text { Cancer in general, breast, colon, CNS, } \\
\text { kidney, leukemia, lung. Lymphoma, } \\
\text { melanoma, ovary, pancreas, prostate, rectum, } \\
\text { thyroid }\end{array}$ \\
\hline 3 & $\begin{array}{l}\text { Liat, } \\
2014\end{array}$ & Cohort & UK & $\begin{array}{l}94254 \text { females }(43 \%) \\
124940 \text { males }(57 \%)\end{array}$ & NR & NR & $\begin{array}{l}\text { Cancer in general, bladder, bone, brain, } \\
\text { breast, cervix, colon, upper GI, kidney, } \\
\text { larynx, lymphoid leukemia, myeloid } \\
\text { leukemia, liver, lung, Hodgkin's lymphoma, } \\
\text { non-Hodgkin's lymphoma, malignant } \\
\text { melanoma, multiple myeloma, nasopharynx, } \\
\text { meninges, oesophageal, ovarian, pancreatic, } \\
\text { prostate, rectum, salivary gland, non- } \\
\text { melanoma skin cancer, stomach, testis, } \\
\text { thyroid, uterine body }\end{array}$ \\
\hline 4 & $\begin{array}{l}\text { Rugbjerg, } \\
2012\end{array}$ & Cohort & Denmark & $\begin{array}{l}9631 \text { females }(47 \%) \\
10712 \text { males }(53 \%)\end{array}$ & NR & NR & $\begin{array}{l}\text { Cancer in general, malignant melanoma, } \\
\text { nonmelanoma skin cancer, buccal cavity, } \\
\text { stomach, colorectal, liver, lung, urinary } \\
\text { bladder, myeloid leukemia, } \\
\text { gallbladder/biliary tract, brain, non-Hodgkin } \\
\text { lymphoma, multiple myeloma, lymphatic } \\
\text { leukemia }\end{array}$ \\
\hline
\end{tabular}

Abbreviations: HTN: Hypertension; DM: Diabetes mellitus; NR: Not reported. 
Supplementary Table 5A. Risk of bias analysis for cohort studies.

\begin{tabular}{|c|c|c|c|c|c|c|c|c|c|c|}
\hline \multirow[b]{2}{*}{ Author } & \multicolumn{4}{|c|}{ Selection } & \multirow{2}{*}{$\begin{array}{c}\text { Comparability } \\
\text { Comparability } \\
\text { of cohorts on } \\
\text { the basis of the } \\
\text { design or } \\
\text { analysis }\end{array}$} & \multicolumn{3}{|c|}{ Exposure } & \multirow[b]{2}{*}{$\begin{array}{l}\text { Total } \\
\text { quality } \\
\text { score }\end{array}$} & \multirow[b]{2}{*}{$\begin{array}{c}\text { Quality } \\
\text { rank }\end{array}$} \\
\hline & $\begin{array}{l}\text { Representat } \\
\text { iveness of } \\
\text { exposed } \\
\text { cohort }\end{array}$ & $\begin{array}{l}\text { Selection } \\
\text { of the } \\
\text { non- } \\
\text { exposed } \\
\text { cohort }\end{array}$ & $\begin{array}{c}\text { Ascertainment } \\
\text { of exposure }\end{array}$ & $\begin{array}{l}\text { Demonstration } \\
\text { that outcome of } \\
\text { interest was not } \\
\text { present at start } \\
\text { of study }\end{array}$ & & $\begin{array}{l}\text { Assessment } \\
\text { of outcome }\end{array}$ & $\begin{array}{l}\text { Was follow-up } \\
\text { long enough for } \\
\text { outcomes to occur }\end{array}$ & $\begin{array}{c}\text { Adequacy } \\
\text { of follow } \\
\text { up of } \\
\text { cohort }\end{array}$ & & \\
\hline Lin, 2015 & * & $*$ & * & * & $\begin{array}{l}{ }^{* *}(\text { age }, \text { sex } \\
\text { index year })\end{array}$ & $\begin{array}{l}\text { *(National } \\
\text { Cancer } \\
\text { Registry } \\
\text { Database + } \\
\text { follow-up) }\end{array}$ & $\begin{array}{l}\text { *(Until diagnosis } \\
\text { of malignant } \\
\text { disease, death, lost } \\
\text { to follow-up, } \\
\text { withdrew from } \\
\text { database, until end } \\
\text { of study date) }\end{array}$ & & 8 & Good \\
\hline $\begin{array}{l}\text { Peretz, } \\
2016\end{array}$ & $*$ & $*$ & * & & ${ }^{*}($ age, sex $)$ & $\begin{array}{c}\text { *(MHS cancer } \\
\text { registry) }\end{array}$ & $\begin{array}{c}\text { *(Until death, } \\
\text { leaving HMO, } \\
\text { study closure, } \\
\sim 10 \text { y to reflect } \\
\text { onset of motor } \\
\text { symptoms and } \\
\text { diagnosis) }\end{array}$ & & 6 & Good \\
\hline $\begin{array}{l}\text { Park, } \\
2019\end{array}$ & $*$ & $*$ & * & $*$ & ${ }^{* *}$ (age and sex) & & $\begin{array}{c}{ }^{*} \text { (Followed up for } \\
\text { cancer } \\
\text { development until } \\
\text { 2016, from 2010) }\end{array}$ & & 7 & Poor \\
\hline Liat, 2014 & * & $*$ & * & $*$ & $\begin{array}{l}\text { (age, sex, } \\
\text { calendar year of } \\
\text { 1st recorded } \\
\text { admission, } \\
\text { region of } \\
\text { residence, } \\
\text { quintile of } \\
\text { patients' Index } \\
\text { of Deprivation } \\
\text { score) }\end{array}$ & $\begin{array}{l}{ }^{*} \text { (Search for } \\
\text { malignant } \\
\text { cancer using } \\
\text { ICD records } \\
\text { and individual } \\
\text { cancer } \\
\text { outcomes })\end{array}$ & $\begin{array}{l}{ }^{*}(1 \text { Jan } 1999- \\
31 \text { Dec 2011) }\end{array}$ & & 8 & Good \\
\hline $\begin{array}{l}\text { Rugbjerg, } \\
2012\end{array}$ & $*$ & $*$ & $*$ & $*$ & $\begin{array}{c}{ }^{* *}(\text { age, }, \text { sex } \\
\text { calendar period) }\end{array}$ & $\begin{array}{l}\text { *(Danish } \\
\text { Cancer } \\
\text { Registry) }\end{array}$ & $\begin{array}{c}\text { *(From } 1 / 1 / 1977- \\
2008)\end{array}$ & & 7 & Good \\
\hline $\begin{array}{l}\text { Wirdefeldt, } \\
2014\end{array}$ & $*$ & $*$ & $*$ & & $\begin{array}{l}*^{* *}(\text { birth year, } \\
\text { sex) }\end{array}$ & $\begin{array}{l}{ }^{*} \text { (Swedish } \\
\text { Cancer } \\
\text { Register) }\end{array}$ & *(1958-2009) & & 7 & Good \\
\hline $\begin{array}{l}\text { Becker, } \\
2010^{1}\end{array}$ & $*$ & $*$ & $*$ & $*$ & $\begin{array}{l}{ }^{* *}(\text { Age, } \text { gender, } \\
\text { general practice, } \\
\text { diagnosis date, } \\
\text { years of history } \\
\text { in the GPRD } \\
\text { prior to } \\
\text { diagnosis date })\end{array}$ & ${ }^{*}$ & $\begin{array}{c}\text { *(accumulated } \\
\text { person-time until } \\
\text { patient developed } \\
\text { an incident cancer } \\
\text { diagnosis, died, the } \\
\text { medical record } \\
\text { ended, or end of } \\
\text { study was reached } \\
-31 \text { December } \\
2005)\end{array}$ & & 8 & Good \\
\hline Fois, 2010 & $*$ & $*$ & $*$ & & $\begin{array}{c}\text { *(age at entry, } \\
\text { sex, calendar } \\
\text { year of } 1 \text { st } \\
\text { recorded } \\
\text { admission, } \\
\text { interval from } \\
\text { study entry and } \\
\text { district of } \\
\text { residence) }\end{array}$ & $\begin{array}{c}\text { *(ORLS } \\
\text { database })\end{array}$ & $\begin{array}{c}\text { *(date of } \\
\text { subsequent } \\
\text { admission for } \\
\text { cancer, death, or } \\
31 \text { March 1999) }\end{array}$ & & 7 & Good \\
\hline Lo, 2010 & $*$ & * & * & & $\begin{array}{l}\text { *(birth year, } \\
\text { gender, } \\
\text { respondent type) }\end{array}$ & $\begin{array}{l}{ }^{*} \text { KPNCCR } \\
\text { database }\end{array}$ & $\begin{array}{l}\text { *(from time of 1st } \\
\text { membership to } \\
29 \text { February 2008) }\end{array}$ & & 7 & Good \\
\hline
\end{tabular}

${ }^{1}$ Both case-control and cohort studies were conducted. 
Supplementary Table 5B. Risk of bias analysis for case-control studies.

\begin{tabular}{|c|c|c|c|c|c|c|c|c|c|c|}
\hline \multirow[b]{2}{*}{ Author } & \multicolumn{4}{|c|}{ Selection } & \multirow{2}{*}{$\begin{array}{c}\text { Comparability } \\
\text { Comparability of } \\
\text { cases and controls }\end{array}$} & \multicolumn{3}{|c|}{ Exposure } & \multirow[b]{2}{*}{$\begin{array}{l}\text { Total } \\
\text { quality } \\
\text { score }\end{array}$} & \multirow[b]{2}{*}{$\begin{array}{c}\text { Quality } \\
\text { rank }\end{array}$} \\
\hline & $\begin{array}{l}\text { Is the case } \\
\text { definition } \\
\text { adequate? }\end{array}$ & $\begin{array}{c}\text { Represen } \\
\text { tativeness } \\
\text { of the } \\
\text { cases }\end{array}$ & $\begin{array}{l}\text { Selection } \\
\text { of controls }\end{array}$ & $\begin{array}{l}\text { Definition } \\
\text { of controls }\end{array}$ & & $\begin{array}{l}\text { Ascertainment of } \\
\text { exposure }\end{array}$ & $\begin{array}{c}\text { Same method of } \\
\text { ascertainment } \\
\text { for cases and } \\
\text { controls }\end{array}$ & $\begin{array}{l}\text { Non- } \\
\text { response } \\
\text { rate }\end{array}$ & & \\
\hline $\begin{array}{l}\text { Freedman, } \\
2015\end{array}$ & * & * & * & * & ${ }^{* *}($ age and sex) & *(ICD codes used) & * & & 8 & Good \\
\hline Tacik, 2016 & ${ }^{*}$ & $*$ & & $*$ & ${ }^{* *}$ (age and sex) & $\begin{array}{c}\text { "(UKPDSBB, Mayo } \\
\text { Clinic specialists) }\end{array}$ & $*$ & & 7 & Good \\
\hline $\begin{array}{l}\text { Shalaby, } \\
2016\end{array}$ & * & $*$ & * & * & ${ }^{* *}$ (age and sex) & $\begin{array}{l}\text { *(CUMC, published } \\
\text { diagnostic criteria) }\end{array}$ & $*$ & & 8 & Good \\
\hline $\begin{array}{l}\text { Becker, } \\
2010^{1}\end{array}$ & * & * & * & * & $\begin{array}{l}{ }^{* *} \text { (age, gender, } \\
\text { calendar time })\end{array}$ & ${ }^{*}($ records and codes) & * & & 8 & Good \\
\hline $\begin{array}{l}\text { Agalliu, } \\
2019\end{array}$ & * & * & $*$ & & ${ }^{* *}$ (age, ethnicity) & $\begin{array}{l}\text { (self-reported } \\
\text { questionnaire) }\end{array}$ & * & & 6 & Poor \\
\hline $\begin{array}{l}\text { Ruiz- } \\
\text { Martínez, } \\
2014\end{array}$ & * & * & $\begin{array}{l}\text { (Spouses } \\
\text { and } \\
\text { caregivers } \\
\text { of PD } \\
\text { patient) }\end{array}$ & * & & $\begin{array}{c}{ }^{*} \text { (Cancer Registry } \\
\text { from Department of } \\
\text { Health of the Basque } \\
\text { Government) }\end{array}$ & * & & 4 & Poor \\
\hline
\end{tabular}

${ }^{1}$ Both case-control and cohort studies were conducted.

Supplementary Table 6A. Cancer subtypes and number of PD patients included in each cancer group in the primary analysis.

\begin{tabular}{llc}
\hline Cancer group & \multicolumn{1}{c}{ Cancers included } & Number of PD patients \\
\hline Cancer in general & - & 372537 \\
Brain & Brain, malignant brain, benign brain & 307706 \\
Colon, rectal, colorectal & Colorectal, colon, rectal & 373523 \\
Lung & Lung, lung and bronchus & 373415 \\
\multirow{2}{*}{ Melanoma } & Malignant melanoma in situ, malignant melanoma, malignant \\
& $\begin{array}{l}\text { melanoma of skin invasive malignant melanoma, unclassified } \\
\text { Oral cavity }\end{array}$ & 389257 \\
& $\begin{array}{l}\text { Oranoma, cavity, pharyna, lip, oral cavity and pharyngeal, buccal } \\
\text { cavity and pharynx, oral cavity/pharynx }\end{array}$ & 76815 \\
\hline
\end{tabular}

Supplementary Table 6B. Cancer subtypes and number of PD patients included in each cancer group in the genetic analysis.

\begin{tabular}{|c|c|c|c|}
\hline \multirow{2}{*}{ Cancer group } & \multirow{2}{*}{ Cancers included ${ }^{1}$} & \multicolumn{2}{|c|}{ Number of PD patients } \\
\hline & & LRRK2-PD & Idiopathic PD \\
\hline Cancer in general & - & 742 & 4094 \\
\hline Breast & Breast & 742 & 4094 \\
\hline Brain & Brain, meningioma & 632 & 3551 \\
\hline Colon, rectal, colorectal & Colorectal, colon & 711 & 3962 \\
\hline Haematological & $\begin{array}{l}\text { Hematological, leukemia, lymphoma, lymphoma/ } \\
\text { haematologic, haematologic, hematologic/lymphoma }\end{array}$ & 742 & 4094 \\
\hline
\end{tabular}


Supplementary Table 6C. Cancer subtypes and number of PD patients included in each cancer group in the gender analysis.

\begin{tabular}{|c|c|c|c|}
\hline \multirow{2}{*}{ Cancer group } & \multirow{2}{*}{ Cancers included $^{1}$} & \multicolumn{2}{|c|}{ Number of PD patients } \\
\hline & & Female & Male \\
\hline Cancer in general & - & 107182 & 139480 \\
\hline Bladder & Bladder, urinary bladder & 103885 & 135652 \\
\hline Colon & Colon, colorectal & 97551 & 128768 \\
\hline Haematological & $\begin{array}{l}\text { Leukemia, lymphoma, Hodgkin's lymphoma, non-Hodgkin's lymphoma, } \\
\text { myeloid leukemia, lymphatic leukemia, multiple myeloma }\end{array}$ & 107182 & 139480 \\
\hline Liver & Liver & 103885 & 135652 \\
\hline Lung & Lung & 107182 & 139480 \\
\hline Rectal & Rectum & 97551 & 128768 \\
\hline Renal & Kidney & 97551 & 128768 \\
\hline Stomach & Stomach & 103885 & 135652 \\
\hline
\end{tabular}

${ }^{1}$ These cancer subtypes are quoted as they appeared in the original shortlisted studies. 